ÇOMÜ Uluslararası Sosyal Bilimler Dergisi 4 (2), 235-264 , 2019 COMU International Journal of Social Sciences 4 (2), 235-264 , 2019

\title{
Türk Sigortacılık Sektörünün 2007-2018 Yıllarına Ait Performansının Oran Analizi Yöntemi ile Ölçülmesi ve Sektörün Ekonomik Büyüme Üzerindeki Etkisi *
}

\author{
Deniz ÇAKMAK * \\ Feride HAYIRSEVER BAŞTÜRK ${ }^{* * \bullet}$
}

$\ddot{O} z$

Araştırmada, finansal aracılık görevini gören sigorta sektörünün performansının ölçülmesi ve ekonomik büyüme üzerindeki etkisinin incelenmesi amaçlanmıştır. İlk olarak Türk Sigortacılık Sektörünün 2007-2018 yılları arasındaki performansı oran analizi yöntemi ile değerlendirilmiş, ikinci olarak Türkiye'de üretilen toplam primler ile GSYH arasındaki ilişki incelenmiştir. Sigorta şirketlerinde finansal analizin amacı, şirketlerin finansal yapısının dayanıklılığının saptanmasıdır. Sigorta şirketlerinin aktif kaliteleri ödeme gücünün yeterliliği açısından oldukça önemlidir. Sigorta şirketlerinin aktifleri bir yandan getiri sağlarken bir yandan da nakit ihtiyacını karşılayabilecek likidite yapısında olmalıdır. Hayat dışı branşlarda aktif kalitesi ve likidite oranları olması gereken seviyenin altında iken, hayat branşında ise yeterli düzeydedir. Hayat dışı branşta Muallak Hasar Karşlıkları hasar prim oranının artmasına sebep olmuştur. Bileşik oran, hayat dışı branşta hayat branşından daha yüksek olarak görülmektedir. Teknik karşıllk oranlarında sektör genelinde büyük bir sorun gözükmese de, hayat dışı branşta özellikle özsermaye/teknik karşılık oranının hayat branşına göre daha yüksek seyrettiği görülmektedir. Ayrıca toplam primler ile ekonomik büyüme arasında pozitif yönlü bir ilişkinin söz konusu olduğu gözlemlenmiştir.

\section{Measuring The Performance of Turkish Insurance Industry Between 2007-2018 With The Method of Ratio Analysis and The Effect of Turkish Insurance Industry on Economic Growth}

\section{Abstract}

In this study, it is aimed that the performance of the insurance industry which acts as a financial

\footnotetext{
* Bilecik Şeyh Edebali Üniversitesi, Sosyal Bilimler Enstitüsü, Bankacılık ve Finans Anabilim Dalı, Türk Sigortacıllk Sektörünün Etkinlik Analizi ve Ekonomik Büyümeye Etkisi isimli Yüksek Lisans Tezi’nden üretilmiştir.

** Yüksek Lisans öğrencisi, Bilecik Şeyh Edebali Üniversitesi, Sosyal Bilimler Enstitüsü,

denizcakmak_@hotmail.com

(c) Sorumlu yazar

*** Doç. Dr., Bilecik Şeyh Edebali Üniversitesi, Uygulamalı Bilimler Fakültesi, Bankacılık ve Finans Bölümü, feride.basturk@bilecik.edu.tr
} 
intermediary is measured and its effect on economic growth is examined. Firstly, the performance of Turkish Insurance Industry between 2007 and 2018 was evaluated with the method of rate analysis. Secondly, the relation between total premium which is produced in Turkey and GDP was examined. The aim of financial analysis in insurance companies is that durability of financial structure of companies is determined. Asset qualities of insurance companies are very important in terms of adequacy of solvency. The assets of insurance companies must be in a liquidity structure that can meet cash needs on the other hand they provide returns. While the asset quality and liquidity ratios in non-life branches are below the level which is required, it is sufficient in life branches. Outstanding Claim Provisions in non-life branches caused loss premium ratio to increase. It is seen that compounded ratio is higher in the non-life branch than in the life branch. Although there is no major problem in the industry in terms of technical reserves ratios, it is seen that shareholder's equity / technical reserves ratio in nonlife branch is higher than the life branch. In addition, it was observed that there was a positive relation between total premiums and economic growth.

Key Words: Turkish Insurance Industry, Measuring Performance, Ratio Analysis, Economic Growth

\section{GíRIŞ}

Bir finansal sistem içinde, tasarruf sahipleri ile fon ihtiyacı duyanlar arasında fon transferi genellikle finansal aracilarla yapılmakta, finansal aracilar ise genel olarak banka ve sigorta şirketlerinden oluşmaktadır (Mishkin, 2001: 21). Finansal aracilık, alıcı ve satıcıların karşılaşmasını, karşılaşmanın öncesinde ya da sonrasında, işlemin hazırlanması, gerçekleştirilmesi ve neticelendirilmesi süreçlerini içeren hizmetlerin tamamı olarak tanımlanmaktadır. Finansal aracılar, mevduat toplayarak veya poliçe üreterek fon elde ederler. Elde edilen fonlar işletmelere finansman olanağ sağlar (Allen ve Santomero,1998:1461). Böylece tasarruf fazlası olan birimler, fon fazlasını finansal aracılara aktarmış olur. Borçlanmak isteyen birimler de, finansal aracılardan fon ihtiyaçlarını karşılarlar. Finansal aracılık bu yolla, hane halkından işletmelere dolaylı finansman ile tasarruf yönlendirmekte olup, kısa vadeli fonların uzun vadeli yatırımları finanse etmesi fonksiyonunu gerçekleştirir. Bu işlemi gerçekleştirirken kullandığı dolaylı finansman süreci finansal aracılık olarak tanımlanır (Miller ve Pulsinelli, 1985: 58).

Finansal sistemin bir parçası olan sigorta şirketleri, bir dizi finansal işlevleri yerine getirmekte ve içsel büyüme modellerinin gelişmesiyle tanınan belirli kanallar aracıllğıyla ekonomik büyümeye katkıda bulunabilmektedir(Curak, Loncar ve Poposki, 2009:29). Genel anlamda finansal aracıların özelde de sigorta şirketlerinin performansının ölçülmesi ve sektörün güçlü ve zayıf yönlerinin bilinmesi son derece önemlidir.

Performans ve etkinlik değerlendirme yöntemleri genel olarak, parametrik ve parametrik olmayan yöntemler olarak ikiye ayrılmaktadır. Parametrik yöntemler olarak bilinen yaklaşımlar, üretim fonksiyonunun bilindiği varsayımına dayanmakta ve sonrasında fonksiyonun parametreleri tahmin edilmektedir (Öztürk, 2007:21). Parametrik olmayan yöntemler ise, doğrusal programlama tekniğini kullanan, performans değerlendirmesi için herhangi bir üretim fonksiyonuna gerek duymayan, çoklu girdi-çıktı arasında ilişki kurabilen analiz türüdür (Yücel, 2017:19-20). 
Bu kapsamda; tercih edilen performans değerlendirme yöntemlerinden biri de durum saptaması yapılması ve tek girdi ve çıtıyla basit bir biçimde hesaplanması nedeniyle oran analizidir. Oran, finansal tablolarda bulunan herhangi iki kalemin birbiriyle olan ilişkisinin basit sayısal açıklaması olarak ifade edilmektedir (Akgüç, 2015:20). Oran analizi, işletmelerin bilanço ve gelir tablolarında bulunan değerlerin birbirleri ile oranlanması yoluyla yapılan çözümleme türüdür (Aydın, 2010: 48). Az bilgi ile sonuç verebildiğinden ve hesaplanması kolay olmasından dolayı tercih edilen verimlilik ya da etkinlik ölçme yöntemidir (Akgüç, 2015:21-22). Oran analizi; tek girdi ve tek çıtıdan meydana gelen iki birimin birbirleri arasındaki ilişkinin irdelenmesi olarak tanımlanmaktadır(Cooper vd. 2004: 350-351). Oran analizinin hesaplanması pratiktir ve işletmeler, performans değerlendirmede yaygın bir şekilde kullanmaktadırlar. Oran analizi, belirli bir zaman diliminde geçerli olan ve belli göstergeleri ortaya koyan statik bir çözümlemedir. Oran analizinde en iyi birime göre kıyaslama yapılmaz. Bunun yerine oran analizi, bilanço ve gelir tablosunda yer alan değerlerin birbirleriyle, anlamlı bir sonuç ortaya çıkaracak şekilde oranlanmasıyla yapılır (Yücel, 2017:15).

Bir işletmenin finansal durumu ve faaliyet sonuçları belirlenirken, işletmenin finansal tablolarında yer alan verilere oranla, bilanço ve gelir tablosundaki rakamların birbiriyle olan ilişkisi daha fazla önem kazanır. İşletmeler sağlam ya da güçsüz taraflarını görebilmek ve performanslarını ölçmek amacıyla finansal oranları belirlemek isterler(Baker ve Powell, 2005:46). Oranlar, işletmenin, diğer işletmelerle kıyaslanması imkanı vermesinden dolayı önemli bir finansal analiz yöntemidir (Monea, 2009:137). Ayrıca, işletmeler sermaye, karlılık ya da faaliyet etkinliklerinde belirlenmiş oran hedeflerini geliştirebilirler.

Araştırmada, öncelikle Türk sigorta sektörünün genel görünümü ele alınarak finansal aracılık görevini gören sigorta sektörünün performansının ölçülmesi ve ekonomik büyüme üzerindeki etkisinin incelenmesi amaçlanmıştır. İlk olarak Türk Sigortacılık Sektörünün 2007-2018 yılları arasındaki performansı oran analizi yöntemi ile incelenmiş ve hayat ve hayat-dışı branşların geneli olmak üzere olası zayıf ve güçlü yanlar ortaya konulmaya çalışılmıştır. İkinci olarak Türk Sigorta Sektörü’nün ekonomik büyüme üzerindeki etkisi ele alınmıştır. Sektörün mevcut durumuna ve gelişmesine bağlı olarak elde edilen bulgular yorumlanmıştır.

\section{TÜRK SİGORTA SEKTÖRÜNÜN GENEL GÖRÜNÜMÜ}

Türkiye'de sigortacılık işlemleri, hayat ve hayat dışı olarak iki temel gruba ayrılmıştır. Buna göre 2018 yılında hayat ve emeklilik branşında faaliyette bulunan 22 sigorta şirketi yer almaktadır. Hayat dışı branşta ise 38 sigorta şirketi işlem yapmaktadır. 2018 yılında sigortacılık sektöründe 54,6 milyar TL tutarında prim üretilmiştir. Toplam primin 6,9 milyar TL'lik bölümü hayat branşında, 47,7 milyar TL'lik bölümü ise hayat dışı branşlarda üretilmiştir. Hayat branşının toplam prim üretimindeki payı \%12,70’tir. Hayat dışı branşların toplam prim üretimindeki payı ise \%87,30 olarak hesaplanmıştır. Sigorta 
sektörünün sigortalılara 2018 yllında verdiği teminatlar 126,9 trilyon TLyi bulmuştur. Verilen teminatların 125,9 trilyon TL'lik kısmı hayat dışı branşlar kanalıyla, yaklaşık 1 trilyonluk kısmı da hayat branşı kanalıyla gerçekleşmiştir. 2018 yılında sigortacılık sektörü toplam 54,6 milyar TL tutarında prim üretmiş ve sigortalılara 126,9 trilyon TL'lik tutar teminat olarak verilmiştir. Yine 2018 yılında GSYH'nin \%1,36’sı kadar prim üretimi yapılarak sigortalılara, GSYH'nin yaklaşık 34 katına gelen bir tutarda teminat sağlanmıştır. Tablo 1'de, 2007 ve 2018 yıllarına dair faaliyette bulunan sigorta şirketi sayısı, sektörün prim üretimi, teminat tutarları ve prim üretiminin GSYH'ye oranları verilmektedir.

Tablo 1: Türk Sigorta Sektörüne Ait Verileri

\begin{tabular}{|l|c|c|r|r|r|}
\hline & $\begin{array}{c}\text { Hayat Dışı } \\
\text { Branş Şirket } \\
\text { Sayısı }\end{array}$ & $\begin{array}{c}\text { Hayat/Emek- } \\
\text { lilik Branşı } \\
\text { Şirket Sayısı }\end{array}$ & $\begin{array}{l}\text { Prim Üretimi } \\
\text { (Milyon TL) }\end{array}$ & $\begin{array}{l}\text { Teminat Tutarı } \\
\text { (Milyon TL) }\end{array}$ & $\begin{array}{l}\text { Prim Üreti- } \\
\text { mi/GSYH }\end{array}$ \\
\hline $\mathbf{2 0 1 8}$ & 38 & 22 & 54.589 & 126.892 .104 & 1.36 \\
\hline $\mathbf{2 0 1 7}$ & 38 & 22 & 46.556 & 107.186 .731 & 1.41 \\
\hline $\mathbf{2 0 1 6}$ & 37 & 22 & 40.488 & 89.861 .644 & 1.52 \\
\hline $\mathbf{2 0 1 5}$ & 36 & 23 & 31.056 & 86.059 .874 & 1.55 \\
\hline $\mathbf{2 0 1 4}$ & 38 & 24 & 25.991 & 76.526 .843 & 1.45 \\
\hline $\mathbf{2 0 1 3}$ & 36 & 24 & 24.227 & 62.820 .060 & 1.51 \\
\hline $\mathbf{2 0 1 2}$ & 35 & 23 & 19.829 & 49.713 .051 & 1.40 \\
\hline $\mathbf{2 0 1 1}$ & 35 & 23 & 17.130 & 39.163 .051 & 1.32 \\
\hline $\mathbf{2 0 1 0}$ & 34 & 23 & 14.130 & 30.661 .735 & 1.29 \\
\hline $\mathbf{2 0 0 9}$ & 33 & 23 & 12.436 & 24.937 .878 & 1.30 \\
\hline $\mathbf{2 0 0 8}$ & 30 & 23 & 11.780 & 22.676 .538 & 1.24 \\
\hline $\mathbf{2 0 0 7}$ & 29 & 23 & 10.931 & 11.910 .814 & 1.30 \\
\hline
\end{tabular}

Kaynak: Hazine ve Maliye Bakanlığı, Sigorta ve Bireysel Emeklilik Faaliyetleri Hakkında Rapor

Hayat ve emeklilik branşı özelinde şirket sayıları incelendiğinde, on bir yıllık (2007-2018) zaman diliminde 22 ile 24 şirket arasında değiştiği, hayat dışı branşta ise on bir yıllık zaman diliminde 29'dan 38 şirkete yükseldiği görülmektedir. Türk sigorta sektöründe toplam primin GSYH'ye oranı yaklaşık 1,5 seviyelerinde seyretmektedir. Türkiye’deki sigorta sektörünün gelişmekte olduğu ancak GSYH içindeki payının az olması sebebiyle ekonomiye etkisinin görece düşük olduğu söylenebilir.

\section{SÍGORTACILIK SEKTÖRÜNDE ORAN ANALIZİ KULLANIMI VE TEMEL ORANLAR}

Sigortacılık sektöründe de diğer sektörlerdeki işletmeler gibi oran analizinden 
yararlanılmaktadır. Sigorta şirketlerinde finansal analizin amacı, şirketlerin finansal yapısının dayanıklılı̆̆ının saptanmasıdır. Eğer finansal yapıda bir bozulma saptanırsa, bunu geç kalmadan fark etmek ve gerekli tedbirleri almak finansal analizin temel amacıdır.

Sigorta şirketlerinin finansal analizi yapılırken faydalanılan oranlar, Sigorta ve Reasürans Şirketlerinin Mali Bünyelerine İlişsin Yönetmelik'te açıklanan şekliyle; dört başlıkta yoğunlaşmıştır. Bunlar;

- Likidite ve Aktif Kalitesine İlişkin Oranlar,

- Karlılı̆̆a İlişkin Oranlar,

- Sermaye Yeterlilik Oranları

- Faaliyet Oranlarıdır.

\subsection{Likidite ve Aktif Kalitesine İlişkin Oranlar}

Şirketler faaliyetlerini sürdürebilmek amacıyla ödemesi gelen borçları için para ya da paraya çevrilebilecek değerler bulundurmalıdırlar. Şirketler uzun vadeli borçlarını ödeyebilecek kabiliyette olsalar dahi kısa vadeli borçlarını ödeme konusunda sıkıntı çekiyorlarsa, başarısız olabilirler. Bu nedenle şirketler likidite ve aktif kalitesine dair oranları belirleyerek, kısa vadeli borçlarını ödeme kabiliyetlerini ölçmektedirler. Sigorta şirketlerinde, nakit vb. varlıkların değerlendirilmesi ve alacaklılara ya da sigortalılara verdikleri teminatların ödenebileceği güvencesinin verilmesi açısından, likidite ve aktif kalitesi oranları önem arz etmektedir.

Aktif kalitesi ve likiditeye dair oranlar şirketler için kısa vadeli yükümlülükleri döndürebilme kabiliyetini ve işletme için çalışma sermayesinin gerekli seviyede bulunup bulunmadığını yorumlayan oranlardır (Leskay, 2010: 62). Söz konusu grup kapsamında cari oran ve likidite oranı esas alınmaktadır.

Sigorta şirketlerinde cari oran, parasal aktiflerin, matematiksel karşılıklar hariç teknik karşılıklar ve alacaklı hesaplar toplamına bölünmesi yoluyla bulunmaktadır (Başpınar, 2005: 14-19). Finansal aracı olan sigorta şirketleri için aktif kaliteleri ödeme gücünün yeterliliği açısından oldukça önemlidir. Tahvil, hisse sendi ve gayrimenkullere yatırılan aktiflerin bileşiminin, dağılım ve kalitesi genel aktif kalitesini belirlemektedir. Buna göre, sigorta şirketlerinin aktifleri bir yandan getiri sağlarken bir yandan da nakit ihtiyacını karşılayabilecek likidite yapısında olmalıdır.

Sigorta şirketlerinde cari oranın \%150 $(1,5)$ ve üzerinde olması beklenir (Başpınar, 2005: 19). Söz konusu durumda sigorta şirketinin kısa vadeli yükümlülüklerini yerine getirme gücünün yeterli olduğu yorumu yapılmaktadır.

4- Sigorta ve Reasürans ile Emeklilik Şirketlerinin Mali Bünyelerine İlişkin Yönetmelik 
Likidite oranı, sigorta şirketleri için nakit ve menkul değerlerin toplamının matematiksel teknik karşılıklar hariç teknik karşılıklar ile alacaklı hesapların toplamına oranlanması yoluyla hesaplanmaktadır. Oranın hayat dışı branşlar için 1'den düşük olmaması beklenirken; hayat branşında faaliyet gösteren sigorta şirketlerinde 0,975 'ten küçük olmaması gerekir. Buradaki fark, hayat branşının hayat dışı branşa kıyasla daha uzun vadeli işlemler yapmasından kaynaklanmaktadır. (Başpınar, 2005: 14-19).

Araştırma kapsamında incelenen sigorta sektörüne ait oranlar, Hazine ve Maliye Bakanlığı'nca yayınlanan Sigortacılık ve Bireysel Emeklilik Sistemi Hakkında Faaliyet Raporları dikkate alınarak araştırmacı tarafından hesaplanmıştır. Sigortacılık sektörünün performans ölçümünde kullanılan oranlar hayat ve hayat dışı branşlar olmak üzere ayrı ayrı incelenmiştir. 2007-2018 dönemine ait cari oran değerleri Grafik 1'de, likidite oranlar1 Grafik 2'te özetlenmiştir.

\section{Grafik 1: Sigorta Sektörüne Ait Cari Oranlar}

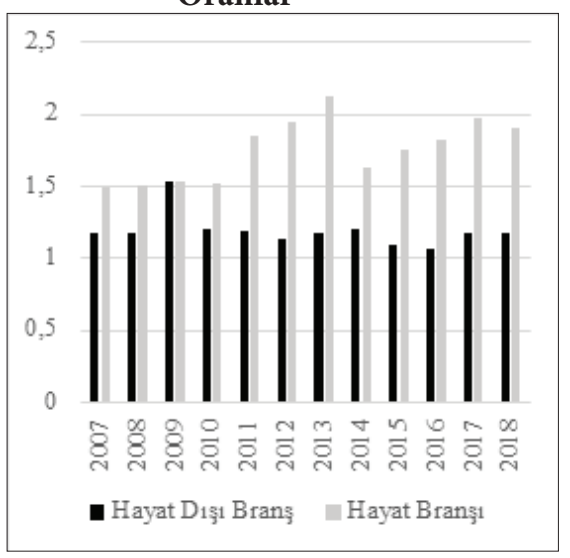

\section{Grafik 2: Sigorta Sektörüne Ait} Likidite Oranları

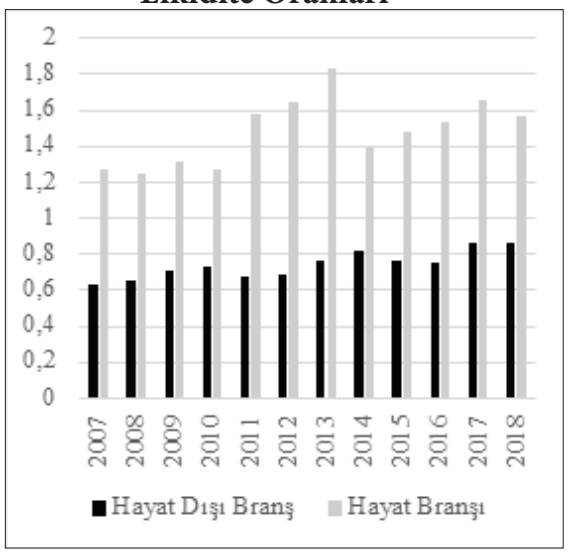

Kaynak: Hazine ve Maliye Bakanlığı, Sigortacılık ve Bireysel Emeklilik Sistemi Hakkında Faaliyet Raporları dikkate alınarak araştırmacılar tarafından hesaplanmıştır.

Grafik 1’e göre, 2007 ve 2009 yılları arasında cari oranın, hayat ve hayat dışı branşlarda arttığı görülmektedir. 2009 ve 2011 yılları arasında hayat ve hayat dışı branşların cari oranında dalgalanmalar gözlenmiş ve hayat branşında düşme gerçekleşmiştir. 2014 yılında cari oranda, hayat branşında düşüş gerçekleşmiştir. 2017 yılında ise cari oran 2016 yılına oranla hem hayat hem de hayat dışı branşı için artış gösterirken, 2018 yılında hayat branşında düşme görülmüştür.

2007 ve 2018 yılları arasında hayat dışı şirketlerin cari oranları, 2009 yılı hariç, olması beklenen oranın altındadır. Bu nedenle hayat dışı branşın aktif kalitesinde sorunlar olduğu anlaşılmaktadır. Buna karşın hayat branşında yer alan sigorta şirketlerinin aktif yapılarında, cari oran özelinde bir sorun görülmemektedir. 2017 yılında hayat branşının 
cari oranı 2'ye yaklaşmıștır. Bu da hayat branşında yer olan sigorta şirketlerinin teknik karşılıklarda ve alacaklılara ödeme yapmada sorun yaşamadıklarını ve kısa dönemdeki yükümlülüklerini yerine getirebilme çabası içinde olduklarını göstermiştir.

Grafik 2'ye göre, likidite oranı 2007 ve 2018 yılları arasında hayat branşında 0,95'in üzerinde bulunmaktadır. Hayat branşında yer alan şirketlerin teknik karşılıklar ve alıcılara ödeme konusunda yeterli olduğu anlamına gelmektedir. Hayat dışı branşlarda likidite oranı, 2007 ve 2018 yılları arasında 1'in altında görülmekte ve genel olarak 0,60 ve 0,80 bandında (2014, 2017 ve 2018 yılları hariç) seyretmektedir. 2014, 2017 ve 2018 yıllarında 0,80 'in biraz üzerindedir.

Hayat dışı branşlarda likidite oranı hayat branşından daha düşüktür. Hayat dışı branşlarda kısa vadeli yabancı kaynak kullanımı daha yoğun olduğundan dolayı likidite oranları daha düşük çıkabilmektedir. Ancak yine de aktif kalitesi oranlarında hayat dışı branşlarda sorun olduğu söylenebilmektedir. İlgili sorunların nakit varlıkların artışından ve teknik karşılık oranlarının değişiminden kaynaklandığı yorumu yapılmaktadır (Berkdemir ve Altun, 2018: 81).

\subsection{Karlılığa İlişkin Oranlar}

Kar, şirketler için temel başarı göstergelerindendir ve şirketlerin faaliyetlerini devam ettirebilmesi için de gereklidir. Sigorta sektöründe ise şirketler, dağıtılmayan karlar sayesinde özsermaye artışı yapmakta böylece ödeme kabiliyetini de yükseltmektedir. Karlılık ile ilgili olarak sigorta şirketlerinin kendine özgü olarak ortaya çıkan iki önemli sorun vardır. Sorunların ilki, afet ya da büyük hasarların olduğu yıllarda sigorta şirketleri büyük miktarlarda tazminat ödemesi yapmak durumunda kalacak ve şirketlerin o yıllarda zarar etmelerine ya da az kar etmelerine neden olabilecektir. Bu yıllarda sigorta şirketlerinin karlılık oranları düşük olurken, uzun dönemdeki karlılık oranları bu olumsuzluktan etkilenmeyebilir. Diğer bir sorun ise, şirketlerin hasar karşılıkları tahminler baz alınarak belirlenmektedir. Beklenmedik durumların yaşanması sonucunda karşılaşılacak sapmalar önceden yapılan tahminlerin tutmamasına neden olabilir (Leskay, 2010: 67). Söz konusu grup kapsamında hasar prim oranı, masraf oranı ve bileşik oran esas alınmaktadır.

Hasar prim oranı, alınan primlerden ne oranda hasar ödemesi yapıldığının göstergesidir (Başpınar, 2005: 15). Oranın sektör ortalamasından daha düşük olması istenir (Berkdemir ve Altun, 2018: 81-82). Sigorta şirketleri için bu oran büyük önem arz etmektedir. Çünkü sigorta şirketleri oranı fiyatlama çalışmalarında kılavuz olarak kullanmaktadır. Sigorta şirketleri hangi branşlarda hasar prim oranının daha yüksek olduğuna bakarak, o branşlarda bir değerlendirme yapmaktadır.

Sigorta şirketleri hasar prim oranlarının yüksek olduğu branşlarda fiyat artışı ya da üretim düşüşü tercihlerini kullanabilmektedir. Ayrıca acente bazında da hasar prim oranı, hangi acentenin daha karlı çalıştığının bulunması amacıyla kullanılmaktadır. Hasar prim oranı sürekli yüksek olan acentelerle ticari manadaki ilişkiler kesilebilmekte ya da hasar prim 
oranı düşük olan acenteler ise ödüllendirilebilmektedir.

Masraf oranı, faaliyetlerden kaynaklanan giderlerin alınan primlere oranlanması yoluyla bulunabilen orandır. Aynı zamanda, sigorta şirketlerinin ürettiği her 1 TL'lik prim kazancına karşılık yüklendikleri masrafları açıklayan oran olarak da tanımlanabilir (Leskay, 2010: 68). Masraf oran1, komisyonlar ve toplam giderlerin net primlere oranlanmasiyla elde edilir. (Başpınar, 2005: 16).

Hasar prim oranı ile masraf oranlarının toplanması yoluyla bileşik oran elde edilir. Bileşik oran, sigorta şirketlerinin ürettiği primlerin hasar için kullanılan bölümünün, üretilen primler için yüklenilen masraflar ile toplanması yoluyla bulunmaktadır. Oran, sigorta şirketlerinin yükümlülüklerini açılamaktadır. Teknik karlılığı ölçmek amacıyla kullanılan temel orandır. Çünkü toplam hasar ödemeleri ve genel giderler, kazanılmış primlerle oranlanır ve şirketin teknik olarak karda olup olmadığı gözlenebilir. Ancak oranın hesaplanabilmesinin önceliği, hasar prim oranının hesaplanmasına bağlıdır. Bu kapsamda sigorta sektörüne ait hasar prim oranları Grafik 3'te, masraf oranları ve bileşik oran Grafik 4'te özetlenmiştir.

\section{Grafik 3: Sigorta Sektörüne Ait Hasar Prim Oranları Grafik}

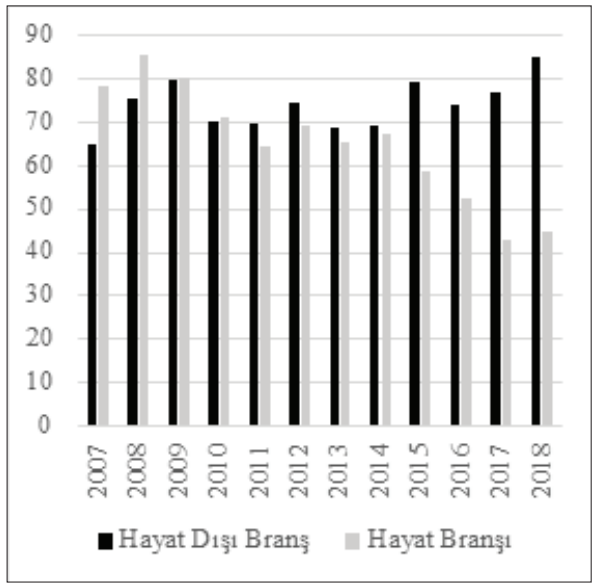

\section{4: Sigorta Sektörüne Ait Masraf ve Bileşik Oran}

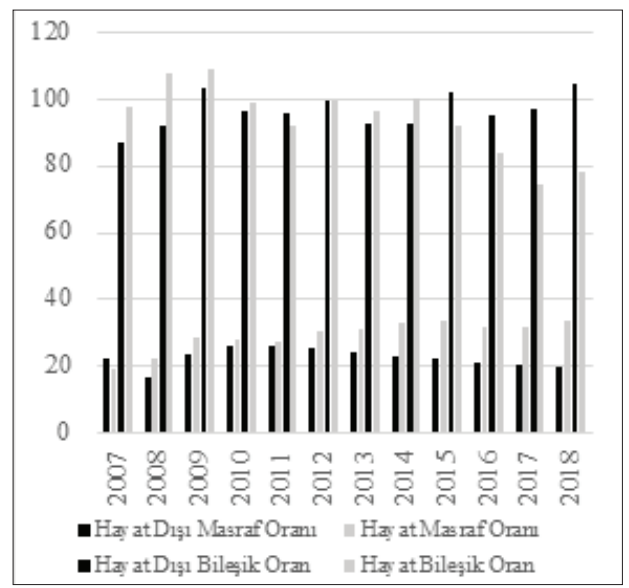

Kaynak: Araştırmacılar tarafından hesaplanmıştır.

Grafik 3’e göre, hayat branşında hasar prim oranın en yüksek olduğu yıl 2008'dir. 2003 ve 2006 yıllarında birikimli hayat sigortalarından bireysel emekliliğe geçişler yaşanması sebebiyle, oluşan iştiralar hasar oranını yükseltmiştir. Bu etki 2008'de tavan seviyeye çıkmıştır. Ancak sonraki yıllarda hayat branşında hasar prim oranı düşüş trendine girerek, 2017 yılında \%43’e kadar düşmüştür. 2018 yılında ise düşük oranlarda artı̧̧ görülmektedir. 
Hayat dışı branşlarda, Muallak Karşılıkları ile ilgili mevzuat değişiikliğinin de sebebiyle 2008-2009 yıllarında hasar prim oranı \%78'e kadar çıkmış, 2009'u takip eden yıllarda düşüş trendine girmiştir. 2015 yılında hasar prim oranında artış gözlenmiş, 2017'de \%77 iken, 2018 yılında \%85 düzeyine çıkmış ve süreç içinde en yüksek değer olarak görülmüştür. Hayat dışı branşlarda hasar prim oranında artma eğilimi göze çarpmaktadır.

Grafik 45'e göre 2007 ve 2018 yılları arasında hayat dışı branşta genel olarak \%20 ve \%26 arasında seyreden masraf oranı; hayat branşında bahsedilen yıllar arasında \%19'dan \%33'ün üzerine bir seyir izlemiştir. Bileșik oran ise, hayat branşında 2009 yılında \% 100'ün üzerindeyken 2017 yllında \%75 seviyelerine gerilemiş, 2018 yllında ise \%78 seviyesine yükselmiştir. Hayat dışı branşta 2007 ve 2017 yılları arasında bileşik oran, dalgalı bir seyir izlemiş ve 2009 yılında \%100'ün üzerindeyken 2017 yılında \%97 seviyelerinde gözlemlenmiş, 2018 yılında ise artış göstererek tekrar \%100'ün üzerine çıkmıştır. İncelenen süreç içinde en yüksek oran \%104 ile 2018 yılında yaşanmıştır. Oranın genel olarak \%98 civarı olması istendiğinden, 2017'de gelinen seviye yeterli görülebilirken, 2018 yılından itibaren orandaki artış eğilimi sektörün dikkatini hasar yönetimine ve poliçe fiyatlandırma süreçlerine çekmektedir.

\subsection{Sermaye Yeterlilik Oranı}

Sermaye yeterlilik oranları, sigorta şirketlerinin orta ve özellikle uzun vadeli yükümlülüklerini karşılama yeteneğini ölçmektedir. Şirketler kısa dönemde zarar edebilir, aktifler iyi yönetilmemiş olabilir ya da fon yaratma konusunda sıkıntı yaşamış olabilirler ancak şirketlerin orta ve uzun dönemde sorumluluklarını karşılamaları yeteneği yine de önem arz etmektedir. Sermaye yeterlilik oranları sigorta şirketlerinin varlığını sürdürebilme yeteneklerini ölçmesi açısından oldukça önemli oranlardır. Bu grup; sermaye yeterlilik oranı, prim/özsermaye oranı, özsermaye/aktif toplamı, teknik karşılıklar ve özsermaye/ teknik karşılıklar oranlarından oluşmaktadır.

Sigorta şirketlerinin sigortalılara karşı olan yükümlülüklerini yerine getirmesi ve istikrarlı olması potansiyel sigortalılara ve piyasalara güvence vermektedir (Kahya, 2001: 161). Sermaye yeterlilik oranı düşük olmayan sigorta şirketleri, olası sigortalılar için daha cazip olabilmektedir. Sigorta şirketleri, kendileri için en uygun ve en verimli sermaye miktarını belirleyerek, hem faaliyetlerine kesintisiz devam edebilir hem de sermayenin maliyetini azaltabilirler. Bu nedenlerle, sermaye yeterlilik oranının çok yüksek olması performansı ters yönde etkileyebilmektedir (Kaya ve Kaya, 2015: 101).

Sigorta şirketlerinin yükümlülükleri ve riskleri sebebiyle ortaya çıkabilecek zararlar için yeterli oranda özsermaye bulundurmaları gerekmektedir. İlgili yönetmelikte ${ }^{6}$ sigorta şirketlerinin gerekli sermaye miktarlarını belirlemek için; yükümlülüklerden doğan risk esaslı yöntem (1. yöntem) ve bilançodaki değerlerden doğan risk esaslı yöntem (2.

\footnotetext{
5- Grafik 4'te, diğerine göre daha kısa çizgiler masraf oranını, uzun çizgiler ise bileşik oranı temsil etmektedir. 6- "Sigorta, Reasürans ve Emeklilik Şirketlerinin Sermaye Yeterliliklerinin Ölçülmesine ve Değerlendirilmesine İlişkin Yönetmelik”, 19.01.2008 tarihli, 26761 sayılı Resmi Gazete
} 
yöntem) olmak üzere iki yöntem tavsiye edilmektedir. İki yöntemde yapılan hesaplamalar sonucunda hangi yöntemde daha büyük özsermaye miktarı bulunmuş ise, o özsermaye miktarı sigorta şirketlerinin faaliyetlerini sağlıklı şekilde sürdürmelerini sağlayan özsermaye miktarını vermektedir. Buna göre sermaye yeterlilik oranı şu şekilde ifade edilebilir:

Sermaye Yeterlilik Oranı $=$ Mevcut Sermaye $/$ Gerekli Sermaye

Şirketlerin ilgili yönetmeliğe göre hesaplanan mevcut özsermayeleri, gerekli özsermaye tutarından düşük olmamalıdır.

Prim/Özsermaye oranı, özsermayenin kaç katı prim üretildiğini açıklamaktadır. Oranın 4’ten büyük olmaması istenmektedir (Berkdemir ve Altun, 2018: 84). Oranın 4’ten büyük çıkması özsermayenin yeter seviyede olmadığını ortaya koymakta ve sigorta şirketinin riskini artırmaktadır.

Bu bilgiler ışığında Grafik 5'de sigorta sektörüne ait sermaye yeterlilik oranları, Grafik 6'da ise prim/özsermaye oranı verilmiştir.

Grafik 5'deki sonuçlara göre, şirketlerin sahip olduğu özsermaye miktarı hem hayat branşında hem de hayat dışı branşlarda olması gerekli özsermaye miktarının üzerinde görünmektedir. Çünkü her iki branşta da bahsedilen dönemlerin hiç birinde oran, 1'in altına düşmemektedir. 2017 yılında hem hayat branşında hem de hayat dışı branşlarda sermaye yeterlilik oranında artış gözlemlenirken, 2018 yılında küçük oranlarda düşmeler yaşanmıştır.

İlgili grafiğe göre, prim özsermaye oranında, 2017 yılında hayat dışı sigorta şirketlerinde sermaye yeterlilik oranındaki değişimden kaynaklanan bir azalış, 2018 yılında ise bir artış olmuştur. 2017 yılında, hayat ve emeklilik branşında ise prim özsermaye oranı, prim üretiminde artış yaşanmasının sonucunda yükselmiştir. 


\section{Grafik 5: Sigorta Sektörüne Ait Sermaye Yeterlilik Oranları}

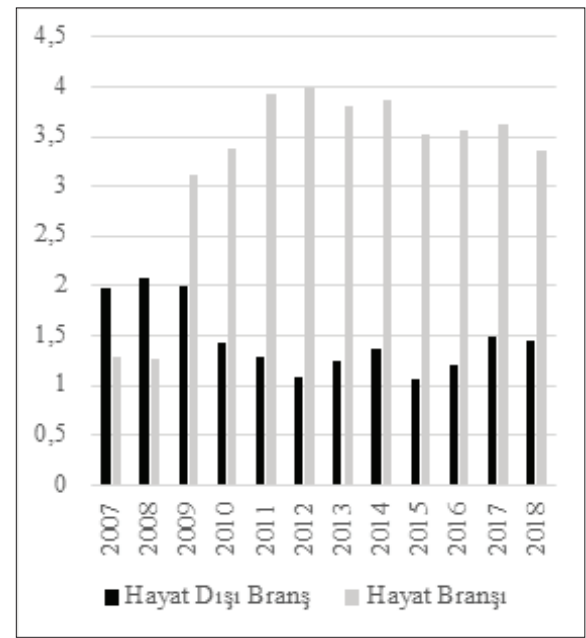

\section{Grafik 6: Sigorta Sektörüne Ait Prim/ Özsermaye Oranı}

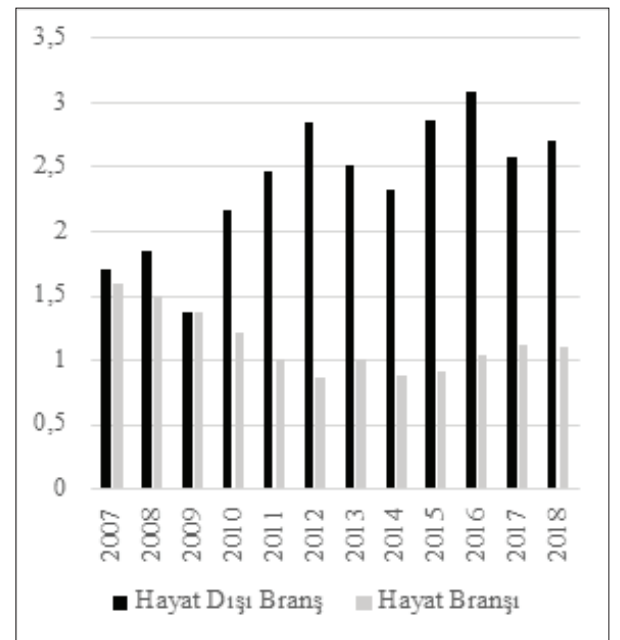

Kaynak: Araştırmacılar tarafından hesaplanmıştır.

Yine 2016 yılında prim üretimlerindeki artışa bağlı olarak prim/özsermaye oranı hem hayat branşında hem de hayat dışı branşlarda artmıştır. 2015 yılında sermaye yeterlilik oranının düşmesine bağlı olarak hem hayat dişı hem de hayat branşlarında prim/özsermaye oranı artmıştır. 2014 yılında ise yine sermaye yeterliliği oranının değişimi sonucu prim/ özsermaye oranı düşmüştür. 2010, 2011 ve 2012 yıllarında prim/özsermaye oranı hayat dışı branşlarda yükselmiş; hayat ve emeklilik branşlarında ise düşüş göstermiştir. $\mathrm{Bu}$ durum hayat ve emeklilik şirketlerinde özsermaye artış hızının prim artış hızından daha yüksek olduğunu göstermektedir. Türk sigorta sektöründe ortalama sermayenin 1,5 katı kadar prim üretilmektedir (Sigortacilık ve BES Faaliyet Raporu, 2017: 45). Ancak 2009 ve 2010 yıllarında hayat ve emeklilik şirketlerinde özsermaye primden daha fazla oranda artığından, prim/özsermaye oranı düşüş göstermiştir.

Özsermaye/Aktif Toplamı oranı, sigorta şirketinin uzun vadeli borçlarını ödeyebilme kabiliyeti ile ilgili ipucu vermektedir. Sigorta şirketinin varlıklarının ne oranda şirket sahip/sahipleri tarafından ödendiğini açıklayan bir orandır. Eğer oran zaman içinde yükselmekteyse, şirket yönetiminin başarılı olduğu anlamına gelmektedir (Akdoğan ve Tenker, 2001: 619). Özsermaye/Aktif Toplamı oranının, şirket bazında bakıldığında sektör ortalamasının altında olması istenmektedir (Berkdemir ve Altun, 2018: 84).

Sigorta şirketleri bir takım riskler üstlenirler ve bu riskler gerçekleştiğinde de sigortalıya tazminat ödemesi yapabilmek için karşılıklar ayırırlar. Teknik karşılıklar, sigorta şirketlerinin muhasebesinde kullanılan sigortacılığa özel bir kalemdir ve sigorta şirketleri için yasal zorunluluk dışında ekonomik nedenlerle de ayrılabilmektedir. Teknik karşılık 
rasyosu, teknik karşılık olarak kabul edilen varlıkların teknik karşılıklara bölünmesi yoluyla bulunur (Güleç, 2015: 59). Grafik 7'de özsermaye/aktif toplamı oranları, Grafik 8 'de ise 2008 ve 2018 yılları arasında hayat ve hayat dışı branşlardaki teknik karşılık oranı verilmiştir.

\section{Grafik 7: Sigorta Sektörüne Ait Özsermaye/Aktif Toplamı Oranı}

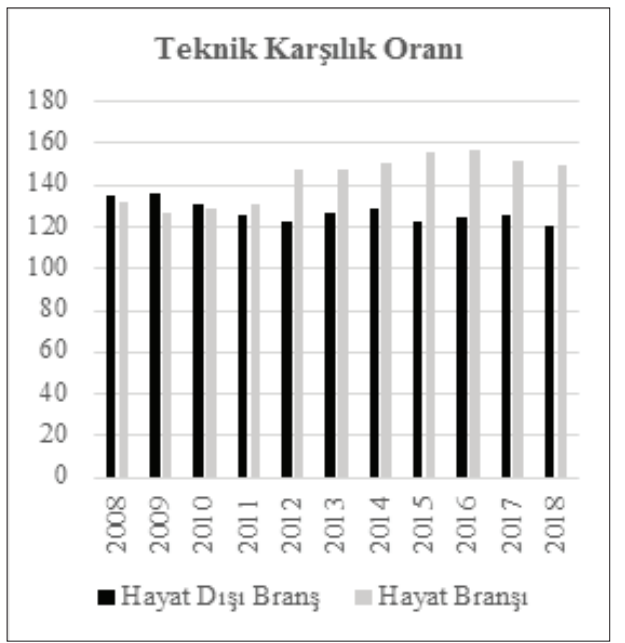

\section{Grafik 8: Sigorta Sektörüne Ait Teknik Karșılık Oranı}

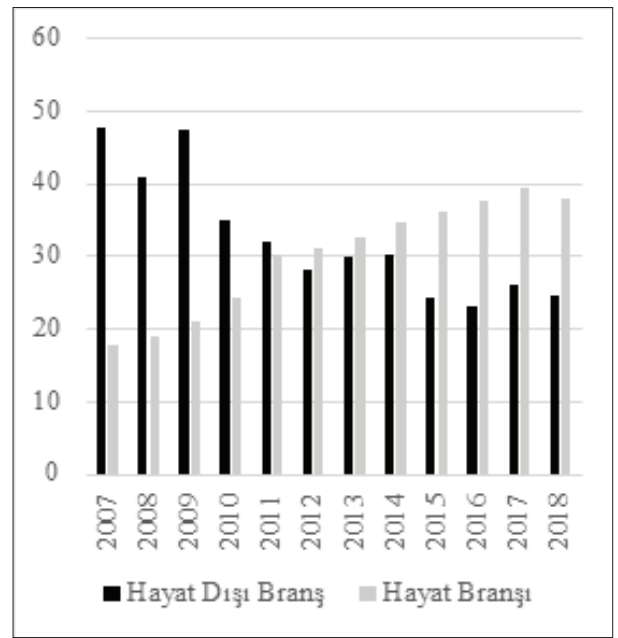

Kaynak: Araştırmacılar tarafından hesaplanmıştır.

Özsermaye/aktif toplamı oranın, hayat dışı branşlarda azalan seyir izlerken; hayat branşında ise artan bir seyir izlediği görülmektedir. Buna göre, hayat dışı branşlarda uzun dönemde borçları ödeme gücü azalırken; hayat branşında ise uzun dönemde yükümlülüklerini yerine getirme gücü artmaktadır. Ayrıca orana göre, hayat branşında yer alan sigorta şirketlerinin yönetim başarısı, hayat dışı şirketlere kıyasla daha yüksek olmaktadır. 2018 yılında söz konusu değerlerde tersine bir hareket görülmekle birlikte oranın ilerleyen yıllardaki seyri önem kazanmıştır.

Grafik 8'deki mevcut sonuçlara göre sigorta şirketleri, belirtilen yıllar boyunca hayat ve hayat dışı branşlarda teknik karşılıklar oranında sıkıntı yaşamamaktadır. Sektörün istikrarı için olumlu bir durumdur. Hayat branşı 2010'dan sonra teknik karşılık oranını sürekli artırmış ancak 2017 yılında yaklaşık 5 puanlık düşüş yaşamış ve 2018 yılında da düşüş eğilimi devam etmiştir. Hayat dışı branşlarda son üç yılda (2015, 2016 ve 2017 yıllarında) teknik karşılık oranı az miktarlarda da olsa artış göstermeye devam etmişken, 2018 yılında değerlerde düşme yaşanmıştır.

Özsermaye/Teknik Karşılık oranı, teknik karşılıklarının ne kadarının özkaynakların 
finansmanında kullanıldığı hakkında bilgi vermektedir. Oranın 1'den (\%100'den) büyük olması istenir (Berkdemir ve Altun, 2018: 84; Başpınar, 2005: 14). Özsermaye/teknik karşılık oranı, risk yönetimi için de önemlidir. Ayrıca özsermayenin teknik karşılıklara bölünmesiyle bulunan oran sermaye yeterliliği konusunda da bilgi verebilmektedir.

Sigorta şirketlerinin sorumluluklarını karşılamak amacıyla ayırmak zorunda oldukları teknik karşılıklar, 5684 Sayılı Sigortacılık Kanunu çerçevesinde gerçekleştirilen mevzuat değişiklikleri neticesinde önemli oranda artmıştır. "Sigorta ve Reasürans ile Emeklilik Şirketlerinin Teknik Karşılıklarına ve Bu Karşılıkların Yatırılacağı Varlıklara İlişkin Yönetmelik” kapsamında, sigorta şirketleri toplam 6 kalemde karşılık ayırırlar. Teknik karşılıklar; kazanılmamış primler karşılığı, devam eden riskler karşılığı, dengelenme karşılığı, matematik karşılıklar, muallak tazminat karşılığı ve ikramiye-indirimler karşılığıdır. İlgili yönetmelikte 2007, 2010, 2012 ve 2015 yıllarında değişiklikler yapılarak Resmi Gazete’de yayınlanmıştır.7 Sigorta sektörüne ait özsermaye/teknik karşılık oranları Grafik 9'da verilmiştir.

\section{Grafik 9:Sigorta Sektörüne Ait Özsermaye/Teknik Karşılık Oranı}

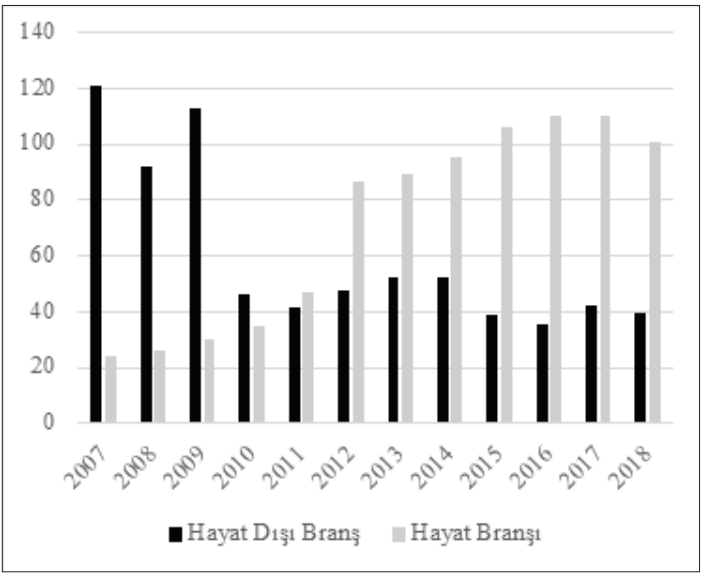

Kaynak: Araştırmacılar tarafından hesaplanmıştır.

Grafik 9 incelendiğinde; hayat dışı branşlarda 2007 ve 2009 yıllarına kıyasla 2010 yılında özsermaye/teknik karşılık oranında düşüş yaşanmıştır. Gözlemlenen sonuç, mevzuat değişikliğine bağlı olarak artırılan teknik karşılıklardan kaynaklanmaktadır. Teknik karşılıkların sürekli artışına paralel olarak özsermayede de artış gözlendiğinden hayat dışı branşlarda son yıllarda büyük değişimler yaşanmamıştır. Buna ek olarak, hayat dışı

7- 07.08.2007 tarihli ve 26606 sayılı Resmi Gazete'de yayınlanan Sigorta ve Reasürans ile Emeklilik Şirketlerinin Teknik Karşılıklarına ve Bu Karşılıkların Yatırılacağı Varlıklara İlişkin Yönetmelik kapsamında 2007, 2010,2012 ve 2015 yıllarında mevzuat değişiklikleri gerçekleşmiştir. 
branşlardan genel sorumluluk sigortaları ve kara araçları sorumluluk sigortalarında prim üretimine ve sermayeye oranla daha yüksek teknik karşılıklar gerektirmektedir. Bu nedenle hayat dışı branşlarda özsermaye/teknik karşılık oranı hayat branşına göre daha düşük kalmaktadır.

\subsection{Faaliyet Oranları}

Sigortacılık sektöründe en çok kullanılan ve bilinen faaliyet oranları, konservasyon ve tazminat tediye oranıdır.

\subsubsection{Konservasyon Oranı}

Konservasyon, sigorta şirketlerinin saklama payı olarak da adlandırılmaktadır. Sigorta şirketlerinin reasüransa devretmeyip üzerlerinde tuttukları riskler konservasyonlardır. Oran, sigorta şirketlerinin üstlendikleri gerçek riski belirtir ve sigorta şirketinin reasürans anlaşmasına gitme sayısı hakkında da bilgi verebilmektedir.

Konservasyon oranı, net alınan primlerin brüt alınan primlere bölünmesi yoluyla bulunabilmektedir. Konservasyon oranının olması beklenen bir değeri bulunmamaktadır. Çünkü sermayesi yüksek şirketlerin konservasyon oranının yüksek olması sigortalılar için sorun teşkil etmezken; sermayesi yeterli olmayan şirketlerin konservasyon oranının yüksek olması şirketin mali durumunun sıkıntılı olduğu anlamına gelebilecektir. Bu nedenle de konservasyon oranı için kesin bir değer belirtmek doğru olmamaktadır (Güleç, 2015:62).

Konservasyon oranı, hayat dışı branşlarda 2007 ve 2018 yılları arasında 0,70 ve 0,83 arasında değişmektedir. Hayat dışı branşta konservasyon oranı en yüksek 0,82 ile 2016 yılında yaşanırken, 2017 yılı için 0,76, 2018 yılı için 0,73 olarak hesaplanmakta ve azda olsa düşme görülmektedir. Hayat branşında oran, aynı yıllar kapsamında 0,73 ve 0,96 değerleri arasında dalgalanmaktadır. İncelenen dönem içinde, oran için en düşük seviyeler 2010 ve 2011 yıllarında sırasıyla 0,74 ve 0,73 olarak yaşanmıştır. 2017 yılına gelindiğinde ise, hayat branşında konservasyon oranının 0,96, 2018 yılında ise 0,95 olarak gerçekleştiği bilinmektedir.

\subsubsection{Tazminat Tediye Oranı}

Cari yıl içinde ödenmiş ve bir önceki yılda muallakta kalmış olup, cari yıla devreden hasarların hangi ölçüde ödenebildiğini belirten bir rasyodur. Sigorta şirketlerinin tazminat tediye oranının yüksek olması sigortalılar için güven verici bir durumdur. Eğer bir sigorta şirketinin tazminat tediye oranı düşükse şirketin hasar ödemelerinde gerekli özen ve hassasiyeti göstermediği anlamına gelebilmekte ve sigortalılarda olumsuz bir izlenim yaratabilmektedir(Leskay: 2010: 66).

Tazminat tediye oranı, gerçekleşen hasarlar ile bu hasarların sigorta şirketlerince ne kadarlık kısmının ödendiğini göstermektedir. Oranın 0,60 ile 0,80 arasında bir değer 
alması beklenmektedir (Başpınar, 2005: 16-20).

Tazminat tediye oranı, hayat dışı branşlarda 2007 ve 2017 yılları arasında 0,75 ve 0,60 aralığında değişmektedir. 2012 yılında oranın 0,74 olduğu bilinmektedir. Oranın diğer yıllara kıyasla daha düşük kaldığı yıl 2008'dir. 2008 yılında tazminat tediye oranı 0,61 olarak hesaplanmıştır. Ancak yine de, tazminat tediye oranı kapsamında hayat dışı branşlarda herhangi bir sorun olmadığı görülmektedir. Çünkü gerçekleşen oranlar ile beklenen değerler arasında bir tutarlılık gözlenmektedir. Oran, hayat branşında da benzer şekilde seyretmektedir.

Hayat ve hayat dişı branşlarda faaliyet gösteren sigorta şirketlerinin sektör rasyoları sigortacılığın geleceğini yorumlamak ve çıkarım yapmak adına önemli göstergeler olarak görülmektedir. Bununla birlikte sigorta sektörünün genel ekonomi içinde almış olduğu pay ve büyümeye olan katkısı da önemli bir göstergedir.

Sigorta şirketlerinin ekonomik büyümeyi sağlamadaki işlevi literatürde pek çok çalışmada açıklanmaya çalışılmıştır. Finansal sistemin önemli bir parçası olan sigortacılık sektörünün özellikle gelişmiş ülkelerde ekonomik büyümeyi pozitif yönde etkilemesi öngörülmektedir. Ancak Türkiye gibi finansal sistemin gelişmekte olduğu ülkelerde ise finansal sistem genellikle bankacılık egemenliğindedir. Dolayısıyla sigortacılık sektörü piyasaların gelişmişlik oranıyla paralel olarak ilerleme göstermektedir. Yine de sigortacılık, finansal aracılık işlevini yerine getirerek ekonomiye katkı sunmaktadır. Bu kapsamda çalışmanın bu bölümünde, Türkiye'de sigortacılık sektörünün ekonomik büyüme üzerindeki etkisinin incelenmesi amaçlanmış ve üretilen toplam primler ile reel gayri safi yurt içi hasıla (GSYH) arasındaki ilişki incelenmiştir.

\section{SİGORTA SEKTÖRÜ VE EKONOMİK BÜYÜME}

Finansal sistemin bir parçası olan sigorta şirketleri, bir dizi finansal işlevleri yerine getirmekte ve içsel büyüme modellerinin gelişmesiyle tanınan belirli kanallar aracılığıyla ekonomik büyümeye katkıda bulunabilmektedir(Curak, Loncar ve Poposki, 2009:29). Finansal gelişme ile ekonomik büyüme arasındaki bağlantıya ilişkin güncel literatür, finansal aracılık teorisini ve içsel büyüme teorisinin iki görüşünü birleştirmektedir.

Finansal aracıların varlığına ilişkin tezleri açıklamak amacıyla geliştirilen finansal aracılık teorisi, mükemmel piyasaya dayalı kaynak tahsisi modellerine belirli katkılar sunar. İlk olarak Gurley ve Shaw (1960) tarafından tanıtılan işlem maliyetlerindeki düşüş, finansal aracıların ana işlevidir. Ölçek ekonomilerinde paylaşılan maliyetlerden dolayı finansal aracıların, doğrudan finansmana göre daha avantajlı olduğu kabul edilmektedir.

Finansal aracıların varlığı için diğer bir tez, ilk olarak Leland ve Pyle (1977) tarafından geliştirilen bilgi asimetrisidir. İlgili çalışmaya göre, finansal aracılar hatalı seçim sorununu 
çözebilmek amacıyla borçluların mali beklentileri konusunda bilgi toplamaktadırlar. Diğer bir deyişle, finansal aracılar sahip oldukları varlıkları özel bilgilere ulaşılabilecek kanallara yatırım yaparak, borçlularına bilinçlendirme hizmeti vermektedirler. Finansal anlamda yaşanan serbestleşme ile ilgili olarak meydana gelen değişiklikler sebebiyle, teknolojik gelişmeler ve mali yenilikler finansal aracılık faaliyetlerinin artmasına neden olmuştur. Bu noktada, Allen ve Santomero (1998) geleneksel yaklaşıma yenilikler önermişlerdir. Allen ve Santomero'nun görüşlerine göre, finansal aracılık teorisi aynı zamanda risk yönetimi işlemlerini ve katılım maliyetlerini düşürmeyi de içermelidir. Hem geleneksel anlamda finansal aracılık teorisini hem de finansal alandaki yenilikleri içerecek biçimde sigorta şirketlerinin mali sistemdeki yerini ve ekonomik büyümeye etkisini anlamak amacıyla, Merton ve Bodie (1995) kaynak tahsisi ve risk yönetimi gibi fonksiyonların altını çizmişlerdir.

Sigorta şirketlerinin faaliyetlerinin ekonomik büyümeye olan etkisini anlamak için bahsedilmesi gereken noktalar; kaynak birikimi ve çeşitli finansal risklerin yönetilmesini ve takasını kolaylaştırma yoluyla tahsisi olarak söylenmektedir. Söz konusu işlevlerin gerçekleştirilmesi ile sigorta şirketleri ekonomik büyümeye etki edebilmektedir. Finansal aracıların fonksiyonlarının ve buradan yola çıkarak sigorta şirketlerinin fonksiyonlarının, ekonomik büyüme ile ilişkisini tanımlamak, içsel büyüme teorisinin gelişmesi ile olası olmaktadir.

Finansal gelişmenin ekonomik büyümeye katkı sunduğunu kanıtlamak amacıyla Pagano (1993) çalışmalar yapmıştır. 1993 yılında yazdığ 1 ve "Financial Markets and Growth" adlı çalışmasıyla finansal anlamdaki gelişmenin, etkin kaynak tahsisinin gerçekleştirilmesi ve işlem maliyetlerinin azaltılması yoluyla, ekonomik büyümeyi destekleyebileceğine dair katkılar sunmuştur. Finansal gelişme finansal aracılık yoluyla ekonomik büyümeye üç şekilde etki edebilmektedir.

Sermayenin Verimliliği: Finansal aracı kurumlar sermayenin verimliliği artırmak yoluyla ekonomiye iki şekilde etki edebilmektedir. Bunların ilki, asimetrik bilgi sorununu gidermek yoluyla bilgi toplayarak alternatif yatırımları değerlendirmektir. Bir diğeri ise, risk paylaşımı yoluyla teknolojik yenilik faydası sunacak ancak riskli olan buna karşılık alternatifine oranla çok daha verimli olabilecek yatırımları öne çıkarmaktır(Pagano, 1993: 615-616)

Tasarrufların işletmelere aktarılması: Finansal aracılık faaliyeti sunarken maliyetlerin en aza indirilmesi daha etkili bir kaynak tahsisi sisteminin geliştirilmesini sağlayacaktır. Bu durum da ekonomik büyümeye doğrudan etki etmektedir(Pagano, 1993: 615).

Tasarruf oranlarını etkilemek: Finansal aracıların tasarruf oranını etkilemesi iki şekilde gerçekleşmektedir. Biri tasarruf miktarı diğeri ise, tasarrufların sistem içindeki hareketliliğindeki verimlilik olarak tanımlanmaktadır (Gross, 2001: 17-21).

Sigorta şirketleri koruma fonksiyonlarını sağlarken, sermayenin marjinal verimliliği, 
tasarruf oranları ve teknolojik ilerleme ile ekonomik büyümeye katkı sunarlar. Sigorta şirketleri zarar eden ekonomik birimlerin zararlarını karşılamaktadır. Ekonomik birimler, yani hane halkları ya da işletmeler, üzerindeki farklı riskleri sigorta şirketlerine devrederek finansal pozisyonlarını belli bir dengede tutabilmektedirler. Üzerindeki risk yükünün bir kısmını devreden bireyler, daha yüksek değerdeki mal veya hizmetleri satın almaya istekli olacaklardır. Böylece, sigorta üretim ve istihdamı teşvik edecek taleplerin yükselmesine ve en nihayetinde de ekonomik büyümenin artmasına neden olmaktadır. Bunun yanı sıra, çalışanların sorumlulukları, malları, hastalıkları, sakatlanmaları ve kilit pozisyonda çalışan personellerin yaşamları ile ilgili riskleri sigorta şirketlerine transfer eden işletmeler, kaynaklarını ve enerjilerini temel faaliyetlerine yönlendirebilirler. İşletmeler, ekonomik büyümeye yüksek oranda katkı sunabilecek gerçek yatırımlar yapmaya cesaret edebileceklerdir (Oke, 2012: 7018-7019).

Sigorta şirketlerinin ortaya çıkardı̆̆ 1 yardımlaşma, havuzlama ve risklerin devredilmesi mekanizmaları olmaksızın mali faaliyetlerin bir kısmı eksik kalacak ve sosyal refaha ulaşma amacı zorlaşabilecektir. Sigortanın kapsam dışı kalması durumunda işletmeler büyük miktarlardaki ihtiyat fonlarına ihtiyaç duyabilirler. Olumsuz olaylarda finansmana erişimi çok sınırlı olan küçük ve orta ölçekli işletmeler için özellikle zor olacaktır. Sigorta, sermayenin marjinal verimliliğini artırarak yüksek geri dönüşü olabilecek projeleri finanse etmek için firmaların yüksek likit fon kaynaklarına ihtiyaç duymayacak şekilde kendilerini güvenceye alabilmelerini sağlamaktadır. Böylece, sigorta şirketleri ekonomik büyümeyi sağlayacak gerçek yatırımları finanse etmek amacıyla fonları korumaya isteklidir (Oke, 2012: 7018-7019).

Hayat kalitesinin artması, yaşam süresinin uzaması, yaşlı nüfus sayısındaki artış trendi, doğum oranlarındaki düşüş, yüksek emekli maaşı ödemeleri beklentisi ve kaliteli sağlık hizmeti isteği gibi değişen demografik haller, sosyal güvenlik sistemi üzerinde baskılara neden olmakta ve bu durum da ekonomik büyümeyi olumsuz etkilemektedir. Ancak, özel sigorta, sosyal güvenlik sistemi üzerindeki baskının azalmasına ve sorunun çözülmesine katkı sunabilir. Emeklilik, hastalık, yaralanma ve işsizliğin finansal yükünden korunmayı sağlar. Hatta hayat, sağlık ya da bireysel emeklilik gibi sigorta türleri devletin sosyal güvenlik sisteminin yerini alabilirler.

Sigorta şirketleri tüm fonksiyonlarını yerine getirirken, üretilen kaynakların bir kısmını ihtiyaçlarının karşılanmasında ve verdiği hizmetlerde kullanır. Eğer sigorta şirketleri kullandıkları kaynakların oranını düşürebilirse ya da diğer bir ifadeyle yatırıma yönlendirilecek olan tasarruf oranını artırabilirse, ekonomik büyümeye katkı sunabilecektir. Tasarruf oranlarını artırabilmenin yollarından biri devralma ve birleşmelerdir. Ayrıca türev ürünlerin kullanılması da daha etkin risk yönetim sürecinin sağlanmasına katkı sağlayacak ve böylece de kaynak kullanımındaki sızma oranının azalmasını sağlayacaktır. Bunlara ek olarak, banka kanalıyla sigortacılık veya internet üzerinden sağlanan sigortacılık da, dağıtım boyutunda maliyetlerin azalmasına ve tasarruf oranlarının artmasına neden olacaktır. Böylelikle, sigorta sektöründe yaşanan tüm bu gelişmeler, ekonomik büyümeyi olumlu etkileyebilecektir (Curak, Loncar ve Poposki 
2009: 34).

Çalışma kapsamında 2010-2018 dönemine ait olmak üzere, Türk sigorta sektörünün ekonomik büyüme üzerindeki etkisinin ölçülmesi amaçlanmış ve araştırmaya eklenmiştir.

\subsection{Araștırmanın Kapsamı ve Yöntemi}

Sigortacılık sektörünün gelişimini ölçmek amacıyla kullanılan bazı göstergeler mevcuttur. Ancak çalışmada sigortacılık sektörünün hem temel çıktılarından olan hem de sektörün gelişmişliğinin bir göstergesi olan toplam primler kullanılmıştır. Bunun yanı sıra ekonomik büyüme ile sigortacılığı ilişkilendirme amacıyla GSYH verilerinden yararlanılmıştır. Çalışmada öncelikle 2010(1)-2018(4) dönemine ilişkin 3 aylık verilerle çalışılarak üretilen toplam primler ile GSYH arasındaki ilişkiyi ortaya çıkarmak amacıyla regresyon analizi yapılmıştır. Kullanılan veri seti T.C. Merkez Bankası EVDS (Elektronik Veri Dağıtım Sistemi) ve www.tsb.org.tr adresindeki resmi istatistiklerden derlenmiştir. Veri setinde yer alan değişkenler reel olarak belirlemiştir. Çalışma kapsamında analizlerin yapılmasında Eviews 10 programından faydalanılmıştır.

\section{Çalışmanın temel hipotezi şu şekildedir.}

$\mathrm{H}_{0}=$ Toplam prim üretimi ekonomik büyümeyi etkilemez.

$\mathrm{H}_{1}=$ Toplam prim üretimi ekonomik büyümeyi etkiler.

Yapılan ekonometrik analiz iki kısımdan meydana gelmektedir. İlk olarak; zaman serilerinin durağan olup olmadığı incelenerek birim kök testleri uygulanmaktadır. Bunun için genişletilmiş Dickey-Fuller (ADF) tekniği kullanılmaktadır (Dickey ve Fuller, 1979: 426-430). İkinci olarak, üretilen primler ve GSYH arasındaki ilişkinin incelenmesi amacıyla regresyon analizi yapılmaktadır. Çalışmada kullanılan model şu şekilde yazılmaktadır:

$\mathrm{Y}=\beta_{1+} \beta_{2} \mathrm{X}+\mathrm{u}$

$\mathrm{Y}=$ Bağımlı Değişken

$\mathrm{X}=$ Bağımsız Değişken

$\boldsymbol{\beta}_{1}=$ Sabit Terim

$\boldsymbol{\beta}_{2}=$ Regresyon Katsayısı

$\mathrm{u}=$ Hata Terimi

GSYH $=\beta_{1}+\beta_{2}$ Toplam Primler $+\mathrm{u}$

Çalışmada, kurulan modelde iki değişken yer aldığı için basit regresyon modeli kullanılmaktadır. Regresyon modellerinin kullanılması için zaman serilerinin durağan olması gerekmektedir. Bunun nedeni durağan olmayan serilerde modellerin çoğunlukla sahte regresyon içermesinin analizlerin sonuçlarının yanlış çıkmasına sebebiyet vermesidir. Bağımlı ve bağımsız değişkenlerde durağanlık söz konusu değilse yapılan regresyonun 
anlamlı olması beklenmemektedir. Dolayısıyla çalışmada, kullanılan değişkenlere ait zaman serilerinin durağanlık bilgilerine başvurulmuş ve durağan zaman serileri elde edebilmek adına serilerin logaritmik yapıları kullanılmıştır.

\subsection{Bulgular ve Bulguların Değerlendirilmesi}

$\mathrm{Bu}$ bölümde öncelikle kurulan model için uygulanan birim kök testinin ve regresyon analizinin sonuçlarına yer verilecektir. Analizde, sabit terimli ve sabit terimli ve trendli ADF istatistikleri ve MacKinnon kritik değerleri ${ }^{8}$ bulunmuştur. Serinin birim kök içerip içermediğini araştırmak kapsamında geliştirilen hipotezler şu şekilde olmaktadır.

$\mathrm{H}_{0}=$ Seride birim kök vardır; seri durağan değildir.

$\mathrm{H}_{2}=$ Seride birim kök yoktur; seri durağandır.

Gerçekleştirilen analizlerin sonucuna göre, toplam prim üretimi ve GSYH değişkenleri sabit terimli ve sabit terimli ve trendli modelde elde edilen ADF değerleri MacKinnon kritik değerlerinden mutlak değer olarak daha küçük olduğundan dolayı zaman serilerinin birim kök içerdiği gerçeğini açıklayan Ho hipotezi reddedilememiştir. Yani değişkenler, kendi seviyelerinde durağan bulunamamıştır ve birim kök içermektedirler.

Zaman serileri kendi seviyelerinde durağan olarak görülmediğinden, farkı alınarak serilerin durağan hale getirilmesi amaçlanmıştır. Çalışmada serilerin birinci farkı alınmış, sabit terimli ve sabit terimli ve trendli modelde GSYH ve toplam primler için hesaplanan ADF değerleri MacKinnon değerlerinden daha küçük olarak bulunmuştur. Seriler, birinci farkları alınarak durağan hale getirilemediğinden, durağan hale gelinceye kadar farkları alınması işlemleri devam etmiştir. Serilerin ikinci farkı alındığında ise, serinin durağan hale geldiği gözlemlenmiştir. Böylece, toplam prim üretimi ve GSYH değişkenleri sabit terimli ve sabit terimli ve trendli modeller kullanılarak durağan hale getirilmiş olup, toplam prim üretimi ikinci farkı seviyesinde $\% 1, \% 5$ ve $\% 10$ anlamlılık seviyelerinde durağandır. Yine GSYH değişkeni, sabit terimli ve sabit terimli ve trendli modeller kullanılarak durağan hale getirilmiş olup, ikinci farkı seviyesinde \%1, \%5 ve \%10 anlamlılık seviyelerinde durağandır. İlgili durum Tablo 2'de ifade edilmektedir.

8- Sabit katsayı ve trendi belirten değerler regresyon testinde var olup, oluşturulan ADF birim kök sıfır kabulü altında Eviews 10 ekonometri programı kapsamında sunulan MacKinnon (1996: 600-620) kritik değerleriyle kıyaslanmıştır. Durağanlık şartının karşılanması için ADF birim kök değerlerinin MacKinnon kritik değerlerinden mutlak değerce büyük olması ve negatif işaret bulundurması gerekmektedir. ADF birim kök testine göre değişkenlerin ikinci düzey farklarında, \%1, \%5 ve \%10 anlamlılık düzeylerinde birim kökün varlığı söz konusu olmamaktadır. 
Tablo 2: Birim Kök Sınaması

\begin{tabular}{|c|r|r|r|r|}
\hline \multirow{2}{*}{ Değişken } & \multicolumn{2}{|c|}{ Sabit Terimli } & \multicolumn{2}{c|}{ Sabit Terimli ve Trendli } \\
\cline { 2 - 5 } & ADF & MacKinnon Krtiği & ADF & MacKinnon Krtiği \\
\hline Intp & -4.048712 & $\% 1-3.699871$ & $-15.25987(2)$ & $\% 1-4.284580$ \\
& $(2)$ & $\% 5-2.976263$ & & $\% 5-3.562882$ \\
& & $\% 10-2.627420$ & & $\% 10-3.215267$ \\
\hline Ingsyh & -7.118936 & $\% 1-3.670170$ & $-4.974844(2)$ & $\% 1-4.356068$ \\
& $(2)$ & $\% 5-2.963972$ & & $\% 5-3.595026$ \\
& & $\% 10-2.621007$ & & $\% 10-3.233456$ \\
\hline
\end{tabular}

İncelenen değişkenlerden yola çıkılarak meydana getirilen model şu şekilde olmaktadır:

Ingsyh $=\beta_{1}+\beta_{2} \operatorname{Intp}+u_{t}$

Bu kapsamda değişkenlere ilişkin olarak tahmin edilen regresyon modeli ve ilgili parametreler Tablo 3'de yer almaktadır.

Tablo 3: Regresyon Analizi Sonuçları

Değişken Büyüklük Std. Sapma t-İstatistik Olasılık

\begin{tabular}{llllr}
\hline \multicolumn{1}{c}{ C } & 4.083981 & 0.556064 & 7.344447 & 0.0000 \\
\multicolumn{1}{c}{ INTP } & 0.774956 & 0.056506 & 13.71462 & 0.0000 \\
\hline R $^{2}$ & 0.846909 & Mean dependent var & 11.70872 \\
Düzeltilmiş R & & & 0.164775 \\
S.E. of regression & 0.842407 & S.D. dependent var & -2.562255 \\
Sum squared resid & 0.065412 & Akaike info criterion & -2.474282 \\
Log likelihood & 48.145479 & Schwarz criterion & -2.531550 \\
F-statistic & 188.0908 & Dannan-Quinn criter. & 1.731512 \\
Prob(F-statistic) & 0.000000 & &
\end{tabular}

Tablo 3'de açılanan parametreler modelde yerine yazıldığında regresyon denklemi şu şekilde olmaktadır:

Ingsyh $=4.08398134827+0.7749556614322^{\star} \operatorname{Intp}$ 
Tablo 3'de yer alan regresyon analizi sonuçlarına göre, oluşturulan model bütünüyle $\% 5$ seviyesinde anlamlı bulunmuştur. P değeri ( $F$ istatistik) \%5’ten küçük olarak gözlenmiştir. Ayrıca modelin açıklayıcılık gücü yüksektir. Çünkü bağımlı değişkendeki (GSYH) değişimlerin \%85’ini bağımsız değişken (toplam primler) açıklamaktadır. Tek bağımsız değişkenin yer aldığı çalışmalarda, modelin açıklama gücü ifade edilirken düzeltilmiş $\mathrm{R}^{2}$ değeri yerine $\mathrm{R}^{2}$ değeri kullanılması sıklıkla tercih edilmektedir (Aydın, 2010:332; Tunalı, 2017:10). Çalışmada kullanılan model tek bağımsız değişken içerdiğinden, modelin açıklama gücünü ifade ederken, düzeltilmiş $\mathrm{R}^{2}$ değeri yerine $\mathrm{R}^{2}$ değeri kullanılmıştır. Buna göre toplam primler ile ekonomik büyüme arasında pozitif yönlü bir ilişki söz konusu iken toplam primlerdeki \%1'lik artış ekonomik büyümede binde 77’lik bir artışa neden olmaktadır. Dolayısıyla çalışmanın başında kurulan "Toplam prim üretimi ekonomik büyümeyi etkilemez" biçimindeki $\mathrm{H}_{0}$ hipotezi reddedilir. Yani, toplam prim üretimi ve ekonomik büyüme arasında olumlu bir ilişki gözlenmiştir.

\section{TARTIŞMA}

Ekonomik kayıplara karşı kalkan vazifesi görmesi nedeniyle sigortacılık sektörü özellikle gelişmiş ekonomilerin önemli bir parçasını oluşturmaktadır. Örneğin sigortacılık sektörünün gelişmişlik ölçütlerinden biri olarak kullanılan kişi başına prim üretimi (Srbinoski, 2016: 32), 2017 yılında Türkiye’de 149\$ iken; gelişmiş piyasalarda 3517\$ olarak bilinmektedir. 2018 yılında ise, Türkiye'de kişi başına prim üretimi 128\$, gelişmiş piyasalarda 3737 olarak ifade edilmektedir. Dolar kurundaki dalgalanmalar, prim üretiminin düşmesinin nedenlerindendir. (Sigortacılık ve BES Faaliyet Raporu, 2018: 1112). Türkiye görece zorlu makro etkenlere rağmen sigortacılık sektöründe sürekli olarak gelişim gösterebilmiştir. Ancak yine de sigortacılığın gelişmiş olduğu ekonomilerin kişi başına prim üretiminin Türkiye'ye oranla yüksek olduğu bilinmektedir. Örneğin, OECD ülkeleri içinde yer alan İngiltere’de 2017 yılında kişi başına düşen sigorta prim tutarı 5112\$; ABD'de 6706\$; İrlanda'da 9532\$; Danimarka’da 6315\$; İsviçre'de 6904\$; Fransa'da 4225\$ ve Lüksemburg'da 41011\$ olarak bilinmektedir. OECD ülkeleri dişında yer alan Çin'de ise 2017 yılında kişi başına düşen sigorta prim tutarı 8270\$ ve Singapur'da 5411\$ olarak görülmektedir (www.stats.oecd.org). Brown, Chung ve Frees (2000)'de, OECD ülkelerinde gelir ve yasal sorumlulukların, sigorta talebini artırdığı, servet ve zarar olasılığının sigorta alımını olumsuz etkilediği sonucuna ulaşılmıştır. Ward ve Zurbruegg (2000), 1961-1996 yılları arasındaki dönemde OECD üyesi ülkeler üzerinde yapılan çalışmanın sonuçları incelendiğinde; sigorta sektörünün ekonomik büyümeyi destekleyip desteklememesi ülkelerin ulusal durumuyla ilgili olmaktadır. Yani bazı ülkelerde sigorta sektörü ile ekonomik büyüme arasında olumlu ilişkiye rastlanırken, bazı ülkelerde ise ilişki saptanamamıştır. Yıldırım (2015), Türkiye'deki sigortacılık sektörünün 2006-2014 yılları arasındaki dönemine ait verilerin analiz edildiği çalışmasında, sigortacılık ile büyüme arasında nedensel bir bağ kurulamamıştır. Sadece ekonomik büyümeden sigortacılığa tek taraflı bir bağdan bahsedilmektedir. Benzer nedenlerle Türkiyede kişi başına düşen prim üretiminin artırılması sürecinde, daha fazla kişinin sigortalı olması ve en temelde 
de sigortalı olma bilincinin geliştirilmesi beklenmektedir. Böylece hem sigorta sektörü belirgin bir gelişme gösterebilir hem de ekonomiye olan etkisi artabilir.

Sigortacılık sektörünün diğer bir gelişmişlik ölçütü olan primlerin GSYH içindeki oranı (penetrasyon) Türkiye'de \%1,42 iken; gelişmiş piyasalarda \%7,76'dır. 2015 yılında üretilen primlerde yaşanan artışlara bağlı olarak penetrasyon oranında artış gözlenmiştir. 2018 yılında ise penetrasyon oranı bir önceki yıla göre küçük bir oranda gerileyerek \%1,36 olmuştur. Bu oran ekonominin gelişmiş olduğu ülkelerde Türkiye'ye oranla daha yüksek olmaktadır. 2017 yılında OECD ülkeleri arasında yer alan İngiltere'de penetrasyon oranı \%12,8; Amerika'da \%11,2; İrlanda'da \%13,6; Fransa'da \%10,6 ve Lüksemburg'da ise \%38,8 olarak bilinmektedir. OECD ülkeleri dışında yer alan ülkelerden Çin'de 2017 yılında penetrasyon oranı \%17,9 ve Singapur'da \%9,4 olarak görülmektedir (www.stats.oecd.org). Beenstock, Dickinson ve Khajuria (1988), Outreville (1990), sigorta primlerinin GSYH ve faiz oranlarıyla ilişkili olduğu kısa ve uzun vadede sigorta primlerinin kişi başına düşen gelirle artış eğilimi içinde olduğu tespit edilmiştir. Browne ve Kim (1993), Hofstede (1995, 2004), Fukuyama (1995), sosyal desteğin sigorta talebini etkilediği sonuçları desteklenmiştir. Bu durum da sayılan ülkelerde ve diğer sigortacılık sisteminin gelişmiş olduğu ülkelerde GYSH içinde sigortacılığın payının yüksek olduğu anlamına gelmektedir.

Türkiye'de ise sahip olunan potansiyelin yüksek olduğu ve sayılan ülkelerdeki seviyeye gelebilmek adına çaba sarfedilmesi gerektiği, GSYH içindeki payının az olması sebebiyle ekonomiye etkisinin de görece düşük olduğu söylenebilir. Karşılaştırmalar göstermektedir ki Türkiye’de sigortacılığın ekonomiye etkisi, gelişmiş ülkelerdeki sigortacılığın gelişmişlik seviyesine ulaşamamıştır. Bu durumun en önemli nedenleri ülke ekonomisinin yaşadığ dalgalanmalar, toplumda sigorta bilincinin yavaş gelişmesi ve zaman zaman sigorta şirketlerinin etkin çalışamamaları olarak sayılabilmektedir. Holsboer (1999)'a göre, sigorta sektörünün ekonomideki yerinin derinleşmesi, artan kaynak miktarına ve finansal sistemdeki yükselen rekabete bağlı olmaktadır. Uzun vadeli tasarrufların artması sermaye piyasasının gelişmesini desteklemekte ve bu yolla ekonomik büyümeye etki edilebilmektedir.

Üçüncü olarak, primlerin büyüme oranları, bir ekonomide sigorta sektörünün gelişimi hakkında bilgi verebilmektedir (Srbinoski, 2016: 32). 2013 ve 2018 yılları arasında prim artış oranı dalgalanma gösterse de hep pozitif seyretmiştir. En dikkat çekici büyüme, 2016 yılında \%26,64 olarak görülmektedir. 2017 yılında ise reel prim artışı \%3,43’te kalmıştır. Bunun en önemli sebebi, hayat dışı sigortalarda prim üretiminde yaşanan artış hızının azalmasıdır. 2017 yılında trafik sigortalarında tavan fiyat uygulamasına gidilmiştir. Hayat dışı sigortaların primlerinin önemli bir kısmını oluşturan trafik sigortası primleri, tavan fiyat uygulaması nedeniyle bir önceki yıldan daha az artış göstermiştir. Hayat dışı sigorta branşında 2017 yılında üretilen primler, bir önceki yıla oranla sadece \%0,1 büyüme gösterebilmiştir. Bu durum da genel prim artış oranlarının azalmasına neden olmuştur. 2018'de prim artış oranı \%17,3’e yükselmiş ve toplamda 54,6 milyar TL prim üretimi gerçekleşmiştir.(Sigortacılık ve BES Faaliyet Raporu, 2018:4). 
Sigorta sektörünün etkin çalışması, sermayenin marjinal verimliliğini artırarak, tasarrufların yatırıma ayrılan kısmını yükselterek ve tasarruf oranlarını değiştirerek ekonomik büyümeye etki etmektedir. Webb, Grace ve Skipper, (2005), Webb, Grace ve Skipper (2002)'de, bankacılık sektörü ile ekonomik büyüme arasında güçlü bir ilişki olduğu, sigorta ile ekonomik büyüme arasındaki ilişkinin ise önemsiz kaldığı yönünde bulgular elde edilmiştir. Arena (2008) de, hayat ve hayat dişı branşlarda gerçekleştirilen faaliyetler ile ekonomik büyüme arasında olumlu ve anlamlı ilişkiye rastlanmıştır. Peter ve Kjell (2006), Chau, Khin ve Teng (2013), Zouhaier (2014)'de hayat sigortası ile ekonomik büyüme arasında zayıf bir ilişki bulunurken, Haiss ve Sümegi (2008), Chen, Lee C., Lee F. (2012)'de, ilişki olumlu gözlenmiştir.

Kugler ve Ofoghi (2005), sigorta sektöründeki büyüme ile ekonomik büyüme arasında nedenselliğin olduğunu ifade ederken, Chau, Khin ve Teng (2013) de bu ilişki gözlenmemiştir. Ayrıca Kugler ve Ofoghi (2005)'deki sonuçlar, sigorta sektörünün büyüklüğü ve sigorta pazarının tüm bileșenleri ile ekonomik büyüme arasında uzun vadeli bir ilişki olduğunu göstermektedir.

\section{SONUÇ}

Araştırmada, finansal sistemin önemli unsurlarından biri olan sigorta sektörü ele alınmış, Türk Sigorta Sektörü’nün performansının ölçülmesi amaçlanmış ve sigorta sektörünün ekonomik büyümeye olan katkısı incelenmiștir.

Sigortacılık sektörüne branşlar özelinde bakıldığında 2017 yılında toplam primlerin \%82,26'sı hayat dışı branşta; 17,74'si hayat branşında üretilmiştir. Benzer şekilde 2018 yılında da üretilen toplam primlerin \%87,32'si hayat dışı branşlarda, \%12,68'i hayat branşında üretilmiştir. 2018 yılında bir önceki yıla göre, üretilen toplam primler içinde hayat dışı branşın payının arttığı görülmektedir. Sigorta şirketlerinin ekonomiye birincil katkısı fon yaratma işlevini yerine getirerek kaynak tahsisini sağlamasıdır. Bu noktada sektörde baskın olan branşın hayat branşı olması istenmektedir. Ancak 2018 ve önceki dönemlere bakıldığında, sigortacılık sektöründe baskın olan branşın hayat dışı branş olduğu anlaşılmaktadır.

Hayat ve hayat dişı branşlarda faaliyet gösteren sigorta şirketlerinin sektör rasyoları sigortacılığın geleceğini yorumlamak ve çıkarım yapmak adına önemli göstergeler olarak görülmektedir. Hayat dışı branşlarda aktif kalitesi ve likidite oranları olması gereken seviyenin altında kalmıştır. Yani hayat dışı branşlarda faaliyet gösteren sigorta şirketlerinin teknik karşılıklar ve sigortalılara ödeme konusunda yeterli olamadığı şeklinde yorumlanmıştır. Hayat branşının aktif kalitesi ve likidite oranlarının yeterli düzeyde olduğu, teknik karşlık ve sigortalılara ödeme konusunda da olumu bir seyir izlediği gözlemlenmiştir. 
2018'de hayat dışı branşta işlem yapan sigorta şirketlerinin hasar prim oranı hayat branşına oranla daha yüksektir. Buna göre, 2017 yılında hayat dışı branşta hasar prim oranı \%77olarak gerçekleşmiş, 2018 yılında ise 2017 yılına göre 8 puan artış göstererek \%85 seviyesine yükselmiştir. Hayat dışı branşta Muallak Hasar Karşılıkları hasar prim oranının artmasına sebep olmuştur. Hayat branşında hasar prim oranı 2007 ve 2018 yılları arasında dalgalı bir seyir izlemiş ve 2018 yılında \%45 olarak gerçekleşmiştir. Bileşik oran hayat dışı branşta hayat branşından daha yüksek olarak görülmektedir. Teknik karşılık oranlarında sektör genelinde büyük bir sorun gözükmese de, hayat dışı branşta özellikle özsermaye/ teknik karşılık rasyosu hayat branşına göre daha yüksek seyrettiği bilinmektedir. Bu durum hayat dışı branşın özellikle sorumluluk sigortalarında yüksek teknik karşılık gösterme zorunluluğundan kaynaklanmaktadır. Ayrıca hayat dışı branşlarda hasar prim oranları son yıllarda yükseliş gösterdiğinden, sigorta şirketlerinin özsermaye artırdığ 1 gözlenmektedir.

Çalışma kapsamında sigorta sektörünün faaliyetleri sonucu üretilen toplam primlerin GSYH üzerinde olumlu etkisi olduğu görülmüştür. Bu sonuç Wadlamannati (2008), Marijuana ve diğ. (2009), Njegomir ve Stojić (2010), Oke (2012), Akinlo ve Apanisile (2014), Ege ve Saraç (2011), Adams ve diğ. (2005), Sarioğlu ve Taşpunar (2011) çalışmaları ile benzerlik göstermektedir.

Elde edilen bulgular kapsamında değerlendirme yapmak gerekirse; sigorta sektörünün ve genel olarak finans sektörünün gelişmesi ile finansal sistem içindeki aracıların rolleri eskiye oranla daha da önem kazanacak ve GSYH üzerindeki payları artış gösterebilecektir. Türkiye bu anlamda potansiyeli olan bir ülkedir ve gelecek yıllarda sigorta sektörünün GYSH'ya olan etkisinin artacağ 1 öngörülmektedir. Sigorta sektörünün gelişim gösterebilmesi, hem genel ekonomik göstergelerin olumlu seyretmesine ve toplumda sigorta bilincinin artmasına hem de sigorta şirketlerinin etkin bir şekilde yönetilmesine bağlı olmaktadır.

2018 yılında hayat ve hayat dışı branşlarda incelenen bazı oranlarda önceki yıllarda var olan eğilimlerin tersine bir dalgalanma görülmüştür. Örneğin; hayat dişı alanda hasar prim ve bileşik oranda artma izlenirken, sermaye yeterlilik oranı, özsermaye aktif toplamı oranı ve teknik karşılıklarda var olan eğilimin tersine hareketler görülmüştür. Hayat alanında ise, hasar prim ve bileşik oranda artma görülürken diğer oranların birçoğunda tersine düşme yaşanmıştır. Bu koşullar altında 2019 yılı büyük önem kazanmakta ve 2018 yılında başlayan dalgalanmanın devam edip etmeyeceği araştırılmalı ve sektörü bekleyen farklı koşullar dikkatle takip edilmelidir. Oran analizinin olası değişiklikler konusunda ön uyarı olarak kullanılabileceği unutulmamalıdır. Ayrıca sektörde faaliyet gösteren sigorta şirketlerinin oranlarının incelenmesi ve sektör ortalamalarına yakınlıkları/uzaklıkları araştırılabilir. Benzer şekilde enflasyon oranlarının branşlar üzerindeki etkisi de yeni araştırmalara konu olabilir.

Bunun yanı sıra sektörün gelişmekte olması bazı sorunlar doğurmaktadır. Sektöre dair yapılan düzenlemeler kapsamında 2004-2005 yılları öncesine ait verilerin toplanmasının 
zorlukları, sektörün geçmiş yıllarının araştırılmasını zorlaştırmaktadır. Ayrıca gelişmekte olan bir sektör olmasından dolayı yasal düzenlemeler ile sürekli olarak desteklenmektedir. $\mathrm{Bu}$ durum sigorta sektörünün daha sağlam temellere sahip olmasını sağlarken diğer yandan bilanço ve finansal tablolarda yer alan kalemlerin isimlerinin ya da hesaplanma yöntemlerinin değişmesine ve dolayısıyla geçmiş verilerle kopukluklar yaşanmasına da sebep olmaktadır. Sektörün finansal sistem içerisinde daha da sağlam bir yer edinmesiyle sorunlar aşılabilecektir.

Sigorta sektörünün poliçe üretimi, Karayolları Motorlu Araçlar Zorunlu Mali Sorumluluk Sigortası (Zorunlu Trafik) ve Kasko Sigortası gibi hasar/prim oranının yüksek olduğu sigorta branşlarında yoğunlaşması sektörün etkinliğini düşürmektedir. Şirketler hasar/ prim oranının düşük seyrettiği daha karlı sigorta branşlarında poliçe üretimini destekleyici çalışmalar geliştirebilirler.

Ayrıca, sigorta sektörü, birçok sektörde olduğu gibi teknolojik ilerlemelerden büyük oranda etkilenmektedir. Bu kapsamda, sigorta şirketlerinin performanslarını ölçmeyi hedefleyen çalışmalar, teknolojik ilerlemenin sigorta sektörünü etkilemesiyle, tamamen ya da kısmen değişim gösterebilecektir. Örneğin yakın bir gelecekte yapay zekanın devreye girmesi söz konusu olabilecek ve çok daha kapsamlı veri setlerinin kullanıldığı algoritmaların geliştirilmesi sonucu sigortacılık bugünkü anlayışının oldukça ilerisine taşınacaktır. Özetle, teknolojik ilerlemeler sigorta sektörünü şuandan öngörülmesi mümkün olamayacak seviyelere taşıyabilecektir. 


\section{KAYNAKLAR}

Adams, M., Andersson, J., Andersson L.F., Lindmark, M. (2005), “The Historical Relation between Banking, Insurance and Economic Growth in Sweden: 1830 to 1998", Norges Handelshøyskole, Department of Economics Discussion Paper SAM, 26.

Akdoğan, Nalan ve Tenker, Nejat (2001), Finansal Tablolar ve Mali Analiz Teknikleri, 7. Baskı, Gazi Kitabevi: Ankara.

Akinlo, T., Apanisile, O. T. (2014) "Relationship between Insurance and Economic Growth in Sub-Saharan African: A Panel Data Analysis” Modern Economy, Vol:5, Issue:2, pp.120-127.

Akgüç, Öztin (2013), Finansal Yönetim, 9. Baskı, Avcıol Basım Yayın: İstanbul.

Allen, F., Santomero, A. (1998) “The Theory of Financial Intermediation”, Journal of Banking and Finance, Vol:21, Issue:11-12, pp. 1461-1485.

Arena, M. (2008), "Does Insurance Market Activity Promote Economic Growth? A Cross Country Study for Industrialized and Developing Countries", The Journal of Risk and Insurance, Vol:75, Issue:4, pp.921-946.

Aydın, Nurhan (2010), Finansal Yönetim, 8. Baskı, Anadolu Üniversitesi Yayınları: Eskişehir.

Aydın, Fatma F. (2010), “Enerji Tüketimi ve Ekonomik Büyüme”, Erciyes Üniversitesi İktisadi ve İdari Bilimler Fakültesi Dergisi”, S:35, ss. 317-340.

Baker, Kent ve Powell Gary E. (2005), Understanding Financial Management A Pratical Guide, 1. Edition, Blackwell Publishing: New Jersey.

Başpınar, Ahmet (2005), "Finansal Analiz Tekniklerinin Sigorta Şirketi Mali Tablolarına Uygulanması”, Maliye Dergisi, S:149, ss.5-35.

Beenstock, M., Dickinson, G., Khajuria, S. (1988) “The Relationship between Property-Liability Insurance Premiums and Income: An International Analysis", The Journal of Risk and Insurance, Vol:55, Issue:2, pp.259-272.

Berkdemir, S. ve Altun N. (2018), “Sigorta Sektöründe Oran Analizi ve Puanlama Yöntemi”, Sakarya İktisat Dergisi, C:7, S:1, ss.70-91.

Brown, M.J., Chung, J.W., Frees, E.W. (2000), "International Property-Liability Insurance Consumption”, Journal of Risk and Insurance, Vol:67, Issue:1, pp.73-90.

Browne M.J., Kim K. (1993), “An international Analysis of life Insurance Demand”, American Risk and Insurance Association, The Journal of Risk and Insurance, Vol:60, Issue:4, pp.616-634.

Chau, W. H., Khin, A. A., Teng, K. L. (2013) "Economic Development Cointegration and Malaysian Life and General Insurance Consumption", Australian Journal of Basic and Applied Sciences, Vol:7 Issue:10, pp.538546.

Chen, P. -F., Lee, C. -C., Lee, C. -F. (2012), "How Does the Development of the Life Insurance Market Affect Economic Growth? Some International Evidence”, Journal International Development, Vol:24, pp.865-893.

Cooper, William W., Seiford, Lawrence M., Zhu, Joe (2004), Handbook on Data Envelopment Analysis, Kluwer Academic: Boston. 
Ćurak, M., Lončar, S., Poposki, K. (2009) "Insurance Sector and Economic Growth in Transition Countries", International Research Journal of Finance and Economics, Vol:34, pp.29- 41.

Dickey, D. A., Fuller, W. A. (1979) "Distribution of the Estimators for Autoregressive Time Series With a Unit Root", Journal of the American Statistical Association, Vol:74, Issue:366, pp.427-431.

Ege, İ., Saraç, T. B. (2011), “The Relationship Between Insurance Sector and Economıc Growth: An Econometrıc Analysı", International Journal of Economics and Research, Vol:2, Issue:2, pp.1-9.

Fukuyama, F. (1995), Trust: The Social Virtues and the Creation of Prosperity, Free Press: New York.

Haiss, P. R., Sümegi, K. (2008), "The Relationship of Insurance and Economic Growth, A Theoretical and Empirical Analysis", Journal of Applied Economics and Economic Policy, Vol:35, Issue:4, pp.405-431.

Hazine ve Maliye Bakanlığı, (2007), Sigortacılık ve Bireysel Emeklilik Sistemi Faaliyet Raporları. [Erişim: 12.09.2018, https://www.hmb.gov.tr/sigortacilik-ve-ozel-emeklilik-raporlari].

Hazine ve Maliye Bakanlığı, (2008), Sigortacılık ve Bireysel Emeklilik Sistemi Faaliyet Raporları. [Erişim: 12.09.2018, https://www.hmb.gov.tr/sigortacilik-ve-ozel-emeklilik-raporlari].

Hazine ve Maliye Bakanlığı, (2009), Sigortacılık ve Bireysel Emeklilik Sistemi Faaliyet Raporları. [Erişim: 12.09.2018, https://www.hmb.gov.tr/sigortacilik-ve-ozel-emeklilik-raporlari].

Hazine ve Maliye Bakanlığı, (2010), Sigortacılık ve Bireysel Emeklilik Sistemi Faaliyet Raporları. [Erişim: 12.09.2018, https://www.hmb.gov.tr/sigortacilik-ve-ozel-emeklilik-raporlari].

Hazine ve Maliye Bakanlığı, (2011), Sigortacılık ve Bireysel Emeklilik Sistemi Faaliyet Raporları. [Erişim: 12.09.2018, https://www.hmb.gov.tr/sigortacilik-ve-ozel-emeklilik-raporlari].

Hazine ve Maliye Bakanlığı, (2012), Sigortacılık ve Bireysel Emeklilik Sistemi Faaliyet Raporları. [Erişim: 12.09.2018, https://www.hmb.gov.tr/sigortacilik-ve-ozel-emeklilik-raporlari].

Hazine ve Maliye Bakanlığı, (2013), Sigortacılık ve Bireysel Emeklilik Sistemi Faaliyet Raporları. [Erişim: 12.09.2018, https://www.hmb.gov.tr/sigortacilik-ve-ozel-emeklilik-raporlari].

Hazine ve Maliye Bakanlığı, (2014), Sigortacılık ve Bireysel Emeklilik Sistemi Faaliyet Raporları. [Erișim: 12.09.2018, https://www.hmb.gov.tr/sigortacilik-ve-ozel-emeklilik-raporlari].

Hazine ve Maliye Bakanlığı, (2015), Sigortacılık ve Bireysel Emeklilik Sistemi Faaliyet Raporları. [Erişim: 12.09.2018, https://www.hmb.gov.tr/sigortacilik-ve-ozel-emeklilik-raporlari].

Hazine ve Maliye Bakanlığı, (2016), Sigortacılık ve Bireysel Emeklilik Sistemi Faaliyet Raporları. [Erişim: 12.09.2018, https://www.hmb.gov.tr/sigortacilik-ve-ozel-emeklilik-raporlari].

Hazine ve Maliye Bakanlığı, (2017), Sigortacılık ve Bireysel Emeklilik Sistemi Faaliyet Raporları. [Erişim: 12.09.2018, https://www.hmb.gov.tr/sigortacilik-ve-ozel-emeklilik-raporlari].

Hazine ve Maliye Bakanlığı, (2018), Sigortacılık ve Bireysel Emeklilik Sistemi Faaliyet Raporları. [Erişim: 28.07.2019, https://www.hmb.gov.tr/sigortacilik-ve-ozel-emeklilik-raporlari].

Hofstede, Geert (1995), “Insurance As a Product of National Values”, Geneva Papers or Risk Insurance, Vol:20, Issue:4, pp.423-429. 
Hofstede, Geert (2004), "A Summary of my Ideas about Organizational Cultures", http://fewed.uvt.nl/center/ hofstede/page4.htm.

Holsboer, Jan H. (1999), "Repositioning of the Insurance Industry in the Financial Sector and its Economic Role", The Geneva Papers on Risk and Insurance - Issues and Practice, Vol:24, Issue:3, pp.243-290.

Gross, Dominique M. (2001), "Financial Intermediation: A Contributing Factor to Economic Growth and Employment”, https://www.researchgate.net/publication/228871897_Financial_Intermediation_A_ contributing_factor_to_economic_growth_and_employment, Social Finance Programme, International Labour Office.

Güleç, Cihan (2015), Türkiye Sigorta Sektöründe Finansal ve Teknik Rasyo Analizi, Yayınlanmamış Yüksek Lisans Tezi, İstanbul Aydin Üniversitesi Sosyal Bilimler Üniversitesi, İstanbul.

Kahya, Mehmet (2001), Sigorta ve Reasürans Şirketlerinde Finansal Analiz, Sentez Reklam ve Danışmanlık Yayınları: İstanbul.

Kaya, E.Ö. ve Kaya, B. (2015), "Türkiye'de Hayat Sigortası Şirketlerinin Finansal Performansını Belirleyen Firmaya Özgü Faktörler: Panel Veri Analizi”, Finansal Araștırmalar ve Çalışmalar Dergisi, C:7, S:12, ss.93111 .

Kugler, M., Ofoghi, R. (2005), "Does Insurance Promote Economic Growth? Evidence from the UK" Money Macro and Finance (MMF) Research Group Conference.

Leland, H.E., Pyle, D.H. (1977), "Informational Asymmetries, Financial Structure, and Financial Intermediation”, The Journal of Finance, Vol:32, Issue:2, pp.371-387.

Leskay, Melek T. (2010), Elementer Alanlarda Faaliyet Gösteren Sigorta Şirketlerinde Finansal Tablo Analizleri ve Bir Uygulama, Yayınlanmış Yüksek Lisans Tezi, Dokuz Eylül Üniversitesi Sosyal Bilimler Enstitüsü, İzmir.

MacKinnon, J. G. (1996) "Numerical Distribution Functions for Unit Root and Cointegration Tests", Journal of Applied Econometrics, Vol:11, pp.601-618.

Marijuana, C., Sandra, L., Lime, P. (2009), "Insurance Sector Development and Economic Growth in Transition Countries". International Research Journal of Finance and Economics, Issue:34.

Merton, R.C., Bodie, Z. (1995), "A Conceptual Framework for Analyzing the Financial Environment”, The Global Financial System, A Functional Perspective, Harvard Business School Press, pp. 3-31.

Miller, Roger L. ve Pulsinelli, Robert W. (1985), Modern Money and Banking, McGraw-Hill: New York.

Mishkin, Frederic S. (2001), The Economics of Money, Banking and Financial Markets, Sixth Edition, Addison Wesley: Boston.

Monea, Mirela (2009), "Financial Ratios-Reveal How a Business is Doing?", Annals of University of Petrosani, Economics, Vol: 9, Issue:2, pp.137-144.

Njegomir, V., Stojić, D. (2010), "Does Insurance Promote Economic Growth: The Evidence from Ex-Yugoslavia Region”, Ekonomska misao i praksa : časopis Sveučilišta u Dubrovniku, Vol:19, Issue:1, pp.31-48.

OECD, (2019), Insurance Statistics. [Erişim: 15.05.2019, https://www.oecd.org/daf/fin/insurance/ oecdinsurancestatistics.htm]. 
Oke, M. O. (2012) "Insurance Sector Development and Economic Growth in Nigeria", African Journal of Business Management, Vol:6, Issue:23, pp.7016-7023.

Outreville, J. François, (1990), “The Economic Significance of Insurance Markets in Developing Countries”, The Journal of Risk and Insurance, Vol:57, Issue:3, pp.487-498.

Öztürk, Yelda (2007), Veri Zarflama Analizi Yöntemi ve Bankacılıkta Verimlilik Analizi, Yayınlanmamış Yüksek Lisans Tezi, Kafkas Üniversitesi Sosyal Bilimler Enstitüsü, Kars.

Pagano, Marco (1993), "Financial Markets and Growth-An Overview", European Economic Review, Vol:37, Issue:2-3, pp.613-622.

Peter R.H., Kjell, S. (2006), “The Relationship of Insurance and Economic Growth, A Theoretical and Empirical Analysis", A Paper for Presentation at the 2006 EcoMod Conference, Hongkong.

Sarioğlu, S. E., Taşpunar, S. (2011), "Sigortacılık Sektörü Ekonomik Büyümeye ve Finansal Sistemin Gelişimine Katkı Sağlayabiliyor mu? Türkiye Örneği (Does Insurance Sector Affect The Economic Growth And Financial Development? Some Evidence From Turkey)", Uluslararası Finans Sempozyumu: Yükselen Ekonomilerde Finansman, Firsatlar, Sorunlar ve Çözümler, Marmara Üniversitesi: İstanbul.

Srbinoski, Bojan (2016), Causality Relationship Between Insurance Development and Economic Growth - The Case of Turkey, Yayınlanmış Yüksek Lisans Tezi, Dokuz Eylül Üniversitesi Sosyal Bilimler Enstitüsü, İzmir.

TCMB, (2019), Gayri Safi Yurtiçi Hasıla. [Erişim: 11.05.2019, https://evds2.tcmb.gov.tr/index.php?/evds/ serieMarket/collapse_21/6000/DataGroup/turkish/bie_gsyhgycf/].

TSB, (2019), Resmi İstatistikler. [Erişim: 02.01.2019, https://www.tsb.org.tr/resmi-istatistikler.aspx?pageID=909].

Tunalı, Halil (2017), “Ekonomik Büyüme ve Sanayileşme İlişkisinde Kaldor Yasasının Türkiye’deki Geçerliliğinin Analizi”, Kırklareli Üniversitesi İktisadi ve İdari Bilimler Fakültesi Dergisi, C:6, S:1, ss.1-15.

Wadlamannati, K. C. (2008), "Do Insurance Sector Growth \& Reforms Effect Economic Development? Empirical Evidence from India” The Journal of Applied Economic Research, Vol:2, Issue:1, pp.43-86.

Ward, D., Zurbruegg, R. (2000), "Does Insurance Promote Economic Growth? Evidence from OECD Countries”, The Journal of Risk and Insurance, Vol:67, Issue:4, pp.489- 506.

Webb, I. P., Grace, M. F., Skipper, H. D. (2002), “The Effect of Banking and Insurance on the Growth of Capital and Output”, Working Paper No. 02-1, Robinson College of Business, Georgia State University, Center for Risk Management and Insurance, Atlanta.

Webb, I., Grace M.F., Skipper, H. (2005), “The Effect of Banking and Insurance on the Growth of Capital and Output", Journal Financial Issues, Vol:2, Issue:2, pp.1-32.

Yıldırım, İsmail (2015), “Development and Economıc Effects of the Insurance Sector in Turkey” International Journal of Economics, Commerce and Management, Vol:3, Issue:4.

Yücel, Leyla İ. (2017), Veri Zarflama Analizi, Der Yayınları: İstanbul

Zhuo, Z. (1998) "Insurance Sector Development and Economic Growth: An Empirical Analysis from China Portfolio Management” University of Manhnheimer.

Zouhaier, Hadhek (2014), "Insurance and Economic Growth", Journal of Economics and Sustainable 
Development, Vol:5, Issue:12, pp.102-112. 